\title{
Identification of a novel plant amalgavirus (Amalgavirus, Amalgaviridae) genome sequence in Cistus incanus
}

\author{
C. J. GOH${ }^{1}$, D. PARK 1 , J. S. LEE ${ }^{1}$, F. SEBASTIANI ${ }^{2}$, Y. HAHN ${ }^{*}$
}

${ }^{1}$ Department of Life Science, Chung-Ang University, Seoul 06974, South Korea; ${ }^{2}$ Institute for Sustainable Plant Protection, Department of Biology, Agriculture and Food Sciences, The National Research Council of Italy, Sesto Fiorentino, Italy

Received February 2, 2018; accepted March 3, 2018

\begin{abstract}
Summary. - Amalgaviridae is a family of double-stranded, monosegmented RNA viruses that are associated with plants, fungi, microsporidians, and animals. A sequence contig derived from the transcriptome of a eudicot, Cistus incanus (the family Cistaceae; commonly known as hoary rockrose), was identified as the genome sequence of a novel plant RNA virus and named Cistus incanus RNA virus 1 (CiRV1). Sequence comparison and phylogenetic analysis indicated that CiRV1 is a novel species of the genus Amalgavirus in the family Amalgaviridae. The CiRV1 genome contig has two overlapping open reading frames (ORFs). ORF1 encodes a putative replication factory matrix-like protein, while ORF2 encodes a RNA-dependent RNA polymerase (RdRp) domain. An ORF1+2 fusion protein, which functions in viral RNA replication, is produced by a +1 programmed ribosomal frameshifting (PRF) mechanism. A +1 PRF motif UUU_CGU, which matches the conserved amalgavirus + 1 PRF consensus sequence UUU_CGN, was found at the boundary of CiRV1 ORF1 and ORF2. Comparison of 25 amalgavirus ORF1 +2 fusion proteins revealed that only three different positions within a 13-amino acid segment were recurrently used at the boundary, possibly being selected so as not to interfere with correct folding and function of the fusion protein. CiRV1 is the first virus found to be associated with the Cistus species and may be useful for studying amalgaviruses.
\end{abstract}

Keywords: Cistus incanus RNA virus 1; Amalgavirus; Cistus incanus; +1 programmed ribosomal frameshifting

\section{Introduction}

Amalgaviruses (the family Amalgaviridae) are doublestranded, monosegmented RNA viruses with one confirmed and two proposed genera, namely Amalgavirus, and "Zybavirus" and "Anlovirus", respectively (Depierreux et al., 2016; Martin et al., 2011; Pyle et al., 2017; Sabanadzovic et al., 2009). Species of the genus Amalgavirus have been isolated from various plants and are known as plant amalgaviruses (Liu and Chen, 2009; Martin et al., 2011; Sabanadzovic et al., 2010;

*Corresponding author. E-mail: hahny@cau.ac.kr; phone: +82-2820-5812.

Abbreviations: AnloV1 = Antonospora locustae virus 1; CiRV1 = Cistus incanus RNA virus $1 ; \operatorname{ORF}(\mathrm{s})=$ open reading frame(s); $\mathrm{PRF}=$ programmed ribosomal frameshifting; RdRp = RNAdependent RNA polymerase; STV = Southern tomato virus
2009). Zygosaccharomyces bailii virus $Z$ ( $Z b V-Z)$, a prototype species of the proposed "Zybavirus" genus, was isolated from the yeast Zygosaccharomyces bailii (Depierreux et al., 2016). Antonospora locustae virus 1 (AnloV1) represents the other proposed genus, "Anlovirus," which infects Antonospora locustae, a microsporidian pathogen of grasshoppers (Pyle et al., 2017). Two additional "Anlovirus" species are associated with giant springtails and two-pronged bristletails, respectively.

The amalgavirus genome contains two open reading frames (ORFs), of which ORF1 encodes a protein of unknown function. The ORF1 protein was initially thought to be a coat protein (Liu and Chen, 2009; Sabanadzovic et al., 2009); however, its predicted tertiary structure has $\alpha$-helical coiled coil, which is uncommon for viral capsid proteins (Nibert et al., 2016; Pyle et al., 2017). The ORF1 protein may thus have an alternate function, such as formation of the replication factory matrix (Isogai et al., 2011; Nibert et 
al., 2016). The second ORF (ORF2), which partially overlaps with ORF1, encodes a RNA-dependent RNA polymerase (RdRp). An ORF1+2 fusion protein, formed by fusing ORF1 and ORF2 using a +1 programmed ribosomal frameshift (PRF) mechanism, is involved in viral RNA genome replication (Depierreux et al., 2016; Nibert et al., 2016).

Amalgaviruses show a phylogenetic relationship to partitiviruses (the family Partitiviridae), which infect plants, fungi, and apicomplexans (Martin et al., 2011; Nibert et al., 2014). They also share similarities in genomic organization with totiviruses (the family Totiviridae), which infect fungi and single-celled eukaryotes (Kondo et al., 2016). Due to the close relationship among these three viral families, amalgaviruses are suggested to represent a transitional intermediate between totiviruses and partitiviruses (Krupovic et al., 2015; Martin et al., 2011; Sabanadzovic et al., 2009).

Transcriptome or metatranscriptome data generated from total RNA isolated from organism or environmental samples often contain sequence reads derived from viral genomic RNAs, which can be identified by comprehensive bioinformatics analysis (Kim et al., 2014; Liu et al., 2012; Nibert et al., 2016). As a result, many plant RNA virus genome sequences were discovered by analyzing transcriptome datasets (Goh et al., 2018; Kim et al., 2018; Park et al., 2018; Park and Hahn, 2017a,b). In this study, a novel plant amalgavirus genome sequence was identified in a transcriptome dataset obtained from leaves of Cistus incanus (the family Cistaceae; commonly known as hoary rockrose).

\section{Materials and Methods}

Transcriptome dataset. The transcriptome dataset analyzed in this study was downloaded from the Sequence Read Archive (SRA) of the National Center for Biotechnology Information (NCBI). The Cistus incanus RNA-seq data obtained from leaves were deposited under Acc. No. SRP093603 (F. Sebastiani, manuscript in preparation) and contained 7.4 gigabases $(\mathrm{Gb})$ of paired-end reads. The sickle program (version 1.33; https://github.com/najoshi/sickle; parameters, -q 30 -155) was used to screen raw RNA-seq reads and high-quality reads were collected. De novo sequence assembly was performed using the SPAdes Genome Assembler (version 3.10.1; parameter, --rna) (Bankevich et al., 2012).

Collection of viral genome sequence contigs. To collect sequence contigs putatively derived from viral genomes, a BLASTx search was carried out against a local viral RNA-dependent RNA polymerase (RdRp) sequence database, using the following parameters: -outfmt 6 -evalue 1e-5 -max_target_seqs 1 -max_hsps 1 . The local RdRp protein sequence database of reported RNA viruses was prepared using sequences obtained from the Pfam database (release 30.0; http://pfam.xfam.org). A total of 345 representative viral RdRp domain sequences, defined by the Pfam database, were obtained from 19 Pfam families with Acc. No. PF00602, PF00603, PF00604,
PF00680, PF00946, PF00972, PF00978, PF00998, PF02123, PF03431, PF04196, PF04197, PF05788, PF05919, PF07925, PF08467, PF08716, PF08717, and PF12426.

Mapping. Mapping of C. incanus RNA-seq reads to a virus genome contig sequence was performed using BWA software (version 0.7.16a-r1181; http://bio-bwa.sourceforge.net) (Li and Durbin, 2009). The variants were called using the SAMtools package (version 1.6; http://www.htslib.org) (Li, 2011).

Sequence comparison. Multiple sequence alignments were generated using MUSCLE software (https://www.drive5.com/muscle) (Edgar, 2004). A phylogenetic tree was inferred by the neighbor-joining method implemented in the ClustalW2 program (http://www.clustal. org) (Larkin et al., 2007). Secondary structure was predicted using the PSIPRED webserver (version 3.3; http://bioinf.cs.ucl.ac.uk/psipred) (McGuffin et al., 2000). Sequence logo representation was generated using the WebLogo webserver (version 3; http://weblogo.threeplusone. com) (Crooks et al., 2004; Schneider and Stephens, 1990).

\section{Results and Discussion}

RNA-seq reads in total of $7.4 \mathrm{~Gb}$ were obtained from C. incanus leaves and assembled into 135,253 transcript contigs. One of the contigs showed a strong amino acid (aa) sequence similarity with a RdRp domain of Southern tomato virus (STV) (UniProt Acc. No. A8R3Y5; Pfam Acc. No. PF02123). STV is the reference virus strain for the genus Amalgavirus of the family Amalgaviridae (Sabanadzovic et al., 2009), suggesting the C. incanus contig was derived from an amalgavirus or related virus genome.

A BLASTx search of the NCBI non-redundant protein database confirmed the contig was related to plant amalgaviruses, including Blueberry latent virus (BLV), Zostera marina amalgavirus 1 (ZmAV1), Zostera marina amalgavirus 2 (ZmAV2), Allium cepa amalgavirus 1 (AcAV1), Allium cepa amalgavirus 2 (AcAV2), Spinach amalgavirus 1 (SpAV1), STV, and Rhododendron virus A (RHV-A) (Martin et al., 2011; Nibert et al., 2016; Park et al., 2018; Park and Hahn, 2017b; Sabanadzovic et al., 2009, 2010). The contig was therefore considered to be derived from a novel plant RNA virus and named Cistus incanus RNA virus 1 (CiRV1). The CiRV1 genome sequence is available in the NCBI nucleotide database under Acc. No. MG833407.

To validate CiRV1 genome sequence homogeneity, raw C. incanus RNA-seq reads were mapped to the CiRV1 genome contig and possible variants were identified. There were 75 polymorphic sites (Supplementary Table S1), indicating the genome contig is a composite sequence derived from a CiRV1 population.

The CiRV1 genome contig was 3323 nucleotides (nt) long and contained two overlapping ORFs (Fig. 1a). ORF1 encodes a 385 aa protein, which showed sequence and structural similarities to ORF1 proteins from other amalgaviruses. 
(a)

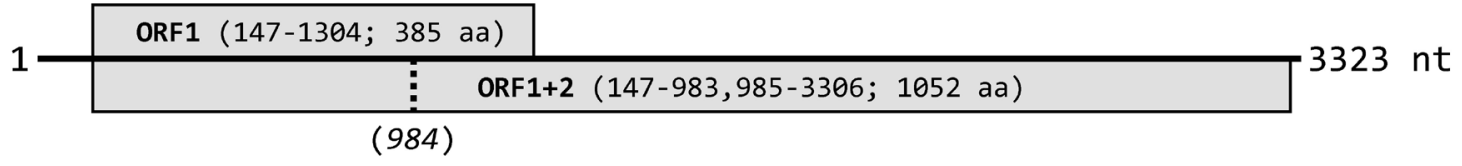

(b)

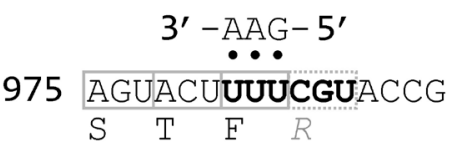

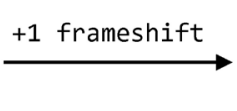

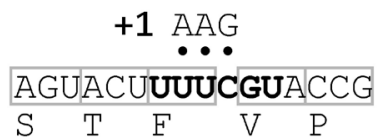

S T F $\quad$ T P

Fig. 1

Genomic structure of CiRV1 and proposed +1 PRF mechanism

(a) Genomic structure of CiRV1. CiRV1 has two overlapping ORFs. ORF1 encodes a 385 aa protein. The ORF1+2 fusion protein is produced by a +1 PRF mechanism and has 1052 aa. Nt position 984, which is skipped by a +1 PRF event, is marked by a dotted line. (b) Proposed +1 PRF mechanism of CiRV1. The CiRV1 +1 PRF region (positions 975-990) is shown. A tRNA ${ }^{\text {Phe }}$ with an anticodon sequence 3'-AAG-5' initially binds to a UUU codon and may slip forward by one nt, thereby causing a $\mathrm{C}$ nt to be skipped at position 984 . The consensus $+1 \mathrm{PRF}$ sequence is indicated in bold letters. Codon-anticodon base pairs are indicated by dots. Codons are marked by boxes. Single letter aa codes below the nt sequence are: $\mathrm{S}$, serine; $\mathrm{T}$, threonine; F, phenylalanine; $\mathrm{R}$, arginine; V, valine; and P, proline.

CiRV1 ORF1 protein was predicted to be exclusively composed of $\alpha$-helices, suggesting it may not function as a coat protein but a replication factory matrix-like protein (Isogai et al., 2011; Krupovic et al., 2015; Pyle et al., 2017).

The second protein encoded by CiRV1 is an ORF1+2 fusion protein that requires a +1 PRF for proper translation. The consensus +1 PRF motif sequence UUU_CGN, where the underscore indicates the ORF1 codon boundary and $\mathrm{N}$ is any nt, is commonly found in amalgaviruses and influenza A virus (Depierreux et al., 2016; Firth et al., 2012; Nibert et al., 2016; Park et al., 2018). In the CiRV1 genome sequence, $a+1$ PRF motif (UUU_CGU) was identified at positions 981-986 (Fig. 1b). Initially, a phenylalanyl-tRNA (tRNA ${ }^{\text {Phe }}$ ) with an anticodon sequence of 3'-AAG-5' would interact with the ORF1 UUU codon. The next codon CGU is a rare arginine codon in eukaryotic organisms, including plants (Li et al., 2016). When the CGU codon is not bound by an arginyl-tRNA for an extended period, a tRNA ${ }^{\text {Phe }}$ positioned on UUU may slip forward by one nt and bind to a UUC triplet, which is in the +1 frame relative to ORF1. As a result, when a +1 PRF occurs, the codon boundary changes from UUU_CGU_A (ORF1) to U_UUC_GUA (ORF2). This process skips a cytosine (C) residue at position 984 , thereby causing a +1 frameshift for continued ORF2 translation. A UUU codon for ORF1 would subsequently be followed by a GUA codon for ORF2.

The CiRV1 +1 PRF motif UUU_CGU matches the consensus sequence UUU_CGN of other amalgavirus +1 PRF sites (Fig. 2). An uracil (U) residue is preferred both at the position before the motif and at the $\mathrm{N}$ position of the motif. Therefore, the most common $7 \mathrm{nt}$ sequence of +1 PRF site is U_UUU_CGU, which was also identified in CiRV1.

The ORF2 component of the CiRV1 ORF1+2 fusion protein begins at nucleotide position 985 , which is the first base after the +1 PRF site. The ORF2-encoded component

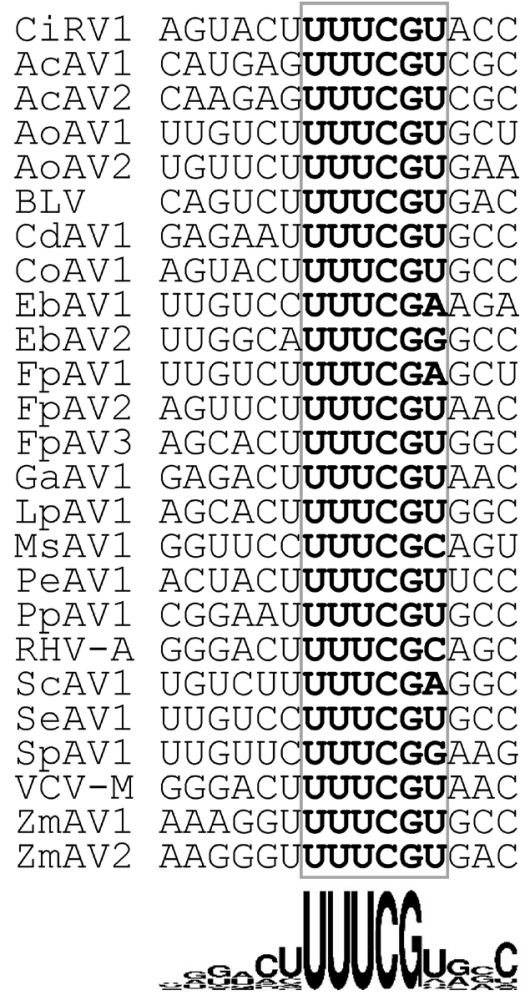

Fig. 2

Comparison of amalgavirus +1 PRF motif sequences Sequences matching the +1 PRF consensus sequence UUU_CGN are marked in bold letters. Sequence logo representation is shown at the bottom. See Table 1 for full virus names.

has 773 aa and has a conserved viral RdRp motif (Pfam Acc. No. PF02123). The CiRV1 ORF1+2 fusion protein has 1052 aa, which may function in CiRV1 genome replication. 
Table 1. Sequence identities of ORF2 proteins of CiRV1 and related viruses

\begin{tabular}{|c|c|c|c|c|}
\hline No. & Acronym & Full name & Accession No. ${ }^{a}$ & Identity with $\mathrm{CiRV} 1^{\mathrm{b}}$ \\
\hline 1 & FpAV2 & Festuca pratensis amalgavirus 2 & GBXZ01002308.1 & $461 / 767(60 \%)$ \\
\hline 2 & FpAV3 & Festuca pratensis amalgavirus 3 & GBXZ01009138.1 & $440 / 767(57 \%)$ \\
\hline 3 & LpAV1 & Lolium perenne amalgavirus 1 & GAYX01076418.1 & $437 / 767(57 \%)$ \\
\hline 4 & BLV & Blueberry latent virus & NC_014593.1 & $399 / 763(52 \%)$ \\
\hline 5 & $\mathrm{ZmAV} 1$ & Zostera marina amalgavirus 1 & NC_034614.1 & $377 / 740(51 \%)$ \\
\hline 6 & $\mathrm{ZmAV} 2$ & Zostera marina amalgavirus 2 & NC_034615.1 & $378 / 745(51 \%)$ \\
\hline 7 & AcAV1 & Allium cepa amalgavirus 1 & NC_036580 & $356 / 721(49 \%)$ \\
\hline 8 & AcAV2 & Allium cepa amalgavirus 2 & NC_036581 & $355 / 722(49 \%)$ \\
\hline 9 & PeAV1 & Phalaenopsis equestris amalgavirus 1 & GDHJ01028335.1 & $371 / 737(50 \%)$ \\
\hline 10 & SpAV1 & Spinach amalgavirus 1 & NC_035070.1 & $341 / 739(46 \%)$ \\
\hline 11 & STV & Southern tomato virus & NC_011591.1 & $364 / 765(48 \%)$ \\
\hline 12 & EbAV1 & Erigeron breviscapus amalgavirus 1 & GDQF01098448.1 & $349 / 760(46 \%)$ \\
\hline 13 & EbAV2 & Erigeron breviscapus amalgavirus 2 & GDQF01120453.1 & $340 / 761(45 \%)$ \\
\hline 14 & CoAV1 & Camellia oleifera amalgavirus 1 & GEFY01004381.1 & $361 / 770(47 \%)$ \\
\hline 15 & GaAV1 & Gevuina avellana amalgavirus 1 & GEAC01063629.1 & $369 / 763(48 \%)$ \\
\hline 16 & CdAV1 & Cleome droserifolia amalgavirus 1 & GDRJ01026949.1 & $344 / 722(48 \%)$ \\
\hline 17 & MsAV1 & Medicago sativa amalgavirus 1 & GAFF01077243.1 & $336 / 718(47 \%)$ \\
\hline 18 & VCV-M & Vicia cryptic virus $M$ & EU371896.1 & $321 / 716(45 \%)$ \\
\hline 19 & RHV-A & Rhododendron virus A & NC_014481.1 & $361 / 777(46 \%)$ \\
\hline 20 & AoAV1 & Anthoxanthum odoratum amalgavirus 1 & GBIE01024896.1 & $340 / 713(48 \%)$ \\
\hline 21 & FpAV1 & Festuca pratensis amalgavirus 1 & GBXZ01049574.1 & $345 / 726(48 \%)$ \\
\hline 22 & $\mathrm{CaAV} 1$ & Capsicum annuum amalgavirus 1 & JW101175.1 & $338 / 746(45 \%)$ \\
\hline 23 & ScAV1 & Secale cereale amalgavirus 1 & GCJW01039808 & $327 / 713(46 \%)$ \\
\hline 24 & PpAV1 & Pinus patula amalgavirus 1 & GECO01025317 & $340 / 728(47 \%)$ \\
\hline 25 & AnloV1 & Antonospora locustae virus 1 & NC_035189.1 & $125 / 536(23 \%)$ \\
\hline
\end{tabular}

${ }^{\mathrm{a}}$ Acc. Nos. of viral genome sequences; ${ }^{\mathrm{b}}$ Amino acid sequence identities have been described in the following format: identical residues/aligned length (\% identity).

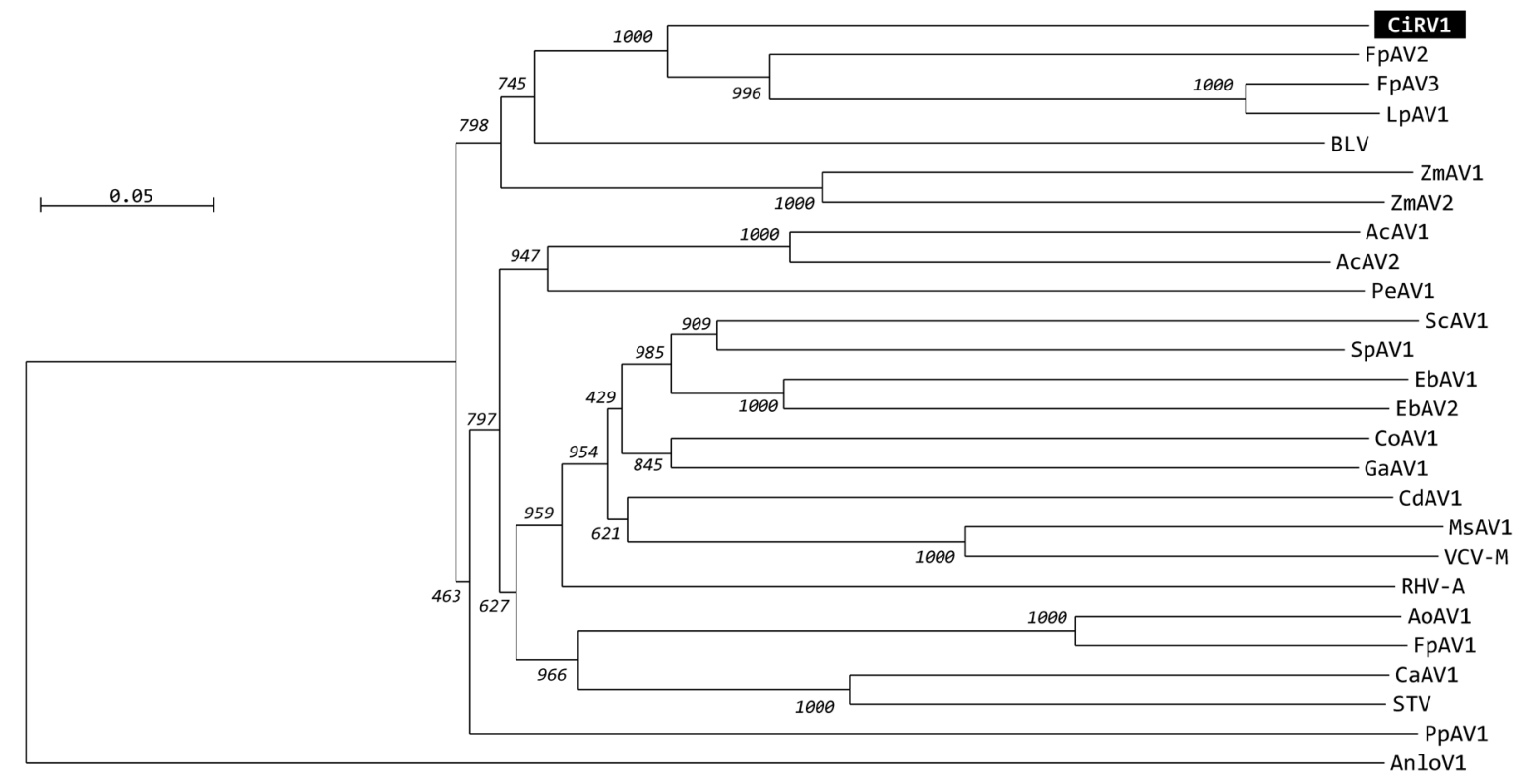

Fig. 3

Phylogenetic tree of CiRV1 and related amalgaviruses

A neighbor-joining phylogenetic tree was inferred based on ORF2 protein sequences. AnloV1 was used as an outgroup. Bootstrap values calculated from 1000 replicates are shown at the nodes. See Table 1 for full name of viruses and aa sequence identity with the CiRV1 ORF2 protein. 
The ORF2 component of the CiRV1 fusion protein showed $45-60 \%$ aa sequence identity with ORF2 proteins previously reported for amalgaviruses (Table 1 ). The virus most closely related to CiRV1 was Festuca pratensis amalgavirus 2 (FpAV2), with $60 \%$ aa sequence identity. The RdRp protein sequence identity threshold for assigning amalgaviruses to different species is 65-70\% (Nibert et al., 2016), indicating that CiRV1 is a novel amalgavirus species. The CiRV1 ORF2 component showed approximately $23 \%$ aa sequence identity with the ORF2 protein of AnloV1, which is a species of the proposed "Anlovirus" genus, a sister genus to the Amalgavirus genus of the family Amalgaviridae (Pyle et al., 2017).

The phylogenetic relationship between CiRV1 and other amalgaviruses was investigated based on a multiple sequence alignment of the RdRp-motif portion of the ORF2 sequence from CiRV1 and 24 other amalgaviruses. A neighbor-joining tree inferred from the ORF2 protein alignment confirmed that CiRV1 belongs to the genus Amalgavirus, of which members are plant amalgaviruses (Fig. 3). CiRV1 formed a strong clade together with FpAV2, Festuca pratensis amalgavirus 3 (FpAV3), and Lolium perenne amalgavirus 1 (LpAV1).

A previous study of the +1 PRF position (at the boundary between ORF1 and ORF2) of ORF1+2 fusion proteins revealed that only three positions are recurrently used in plant amalgaviruses (Park et al., 2018). The multiple sequence alignment of CiRV1 and 24 other amalgavirus ORF1+2 fusion proteins revealed that the CiRV $1+1 \mathrm{PRF}$ also occurred at one of the three positions, designated as positions \#1, \#2, and \#3 (Fig. 4 and Supplementary Fig. S1). The +1 PRF occurs at positions \#1, \#2, and \#3 in 9, 2, and 14 amalgaviruses, respectively. CiRV1 $+1 \mathrm{PRF}$ is at position \#3, which is the most common.

\#1 \#2 \#3

(9) (2) (14)

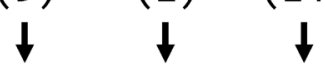

AOAV1 LTALREYVNKKILSFVLVENTGSRPALDTSWLPWTAKLLEKYPLPERISATAMIPMGRTTSP BLV QADLTRYAREKIQSFVTQETREESPVLEISIRQQLEQRLISLPLELRKFHMKQVPFGIPLHK

EbAV1 AVKLFEYAKRKILSFEEMVTSNRKPIGKFTWMPRVETYLLSRPVKLRKRICSMCPVGLPPPP

EbAV2 RTLLLEYCKKKILAFGPIRISDKPHPSRVCWLEQVETWLLSRPVALRREICSLVPVGFPHLP

FPAV1 LHRLREYVGKKILSFELVESGRYPIDLSTSWLPWTASLLMKYPLSERVSATIMIPMGTITEP

SCAV1 QDALMKYLAEQVCLFEATQTTPRPEMENTTWLSLVESRALSWPLPQRKSVLGIVPLGRPPLP

SPAV1 QDIMERFMKERFLFFGRPPMNLGSAQQECSWLALVERKLWKMPLQRRLRLTGMIPIGILQAP

ZmAV1 RDYLLQYCKEKVKGFVPNSKTKELKLIGDTMHARLETYFLRI PLERRGRLLDQI PVGRLTRK

ZmAV2 RDYLLQYCKEKIKGFVTTPIKSALTHSRDTILQRLESHFLKAPLERREELLPLIPVGTVNPM

ACAV1 QIPLKVWADSKLKELADNHEFVASARPSESWVSRVESHLHRLPLPQRVFQANNVPVGPVSQL

ACAV2 QRLLQTWAASKIQDLRTNQEFVASQSSNDSWLSQVETHLWRLPLPLRLKWANTIPVGKVVSR

CAAV1 RDTLSEYLQRLVGLKAGQGRRREVENFVPSWQEWVSQLLMRYPLERRRWLLNRLVVGRINPP

CIRV1 KEKLLSFGRKELKKFEEKNERRQASTFVPQSMSSLESRLLKYPLPTRMKLMKRI PVGIPRAK

COAV1 QQQLMQFLRGKILELDQIHERKQASTFVPYWLQSVVRRLHSRPLQRRLEMMEMI PVGKPNKP

FPAV2 TDALIEFGKQKILRCQEAGSGKLESSFVTYSLSS IQRMLLRYPLAQRKQMMEWIPMGVVPTR

FPAV3 KNAMLNYGKLKIKKLEESKSKRELSTFVASSQSLIHRVLMSRPLKQRKELMAAIPMGVPTLP

GaAV1 RPLMFEYLRKKILQFDAAADTKQAETFVTTWQQLVAQALMRHPLVERQKLANLVPVGRPPLP

LPAV1 KNAMLNYGKLKIKKLAEGKSKRELSTFVASSQSLIHRVLMSHPLKQRKEMMAAIPMGVPLLP

MSAV1 SDFVRDYYNQKIVHLERSGEKKQAGSFAVSWWPLMEKWLLMFPLSTRSTLMEKI PVGKVHKP

PeAV1 RNNLKHWIEEKILELDTVGEARRATTFVPTWQQRVERWLMKFELKLRLELLQQVVLGVPCAE

PPAV1 REALQNYCMRKIKHFEQESNEKQARNFVPSWMQLVSQRLWRLPLSTREREARGIPVGVVRLP

RHV-A QVALRKFADERIHFLDGIGEPKKAGTFAASWQSSVLNLLLRQPLIRRREMMRMI PVGKVMLP

VCV-M AEFIRDYYNQKVLHLDRSGEKKQAGTFVTSWWPDVEKWLLMLPLSQRLSLMEKIPVGKVPSP

CaAV1 VPLLQEYINQKIAHFDAVGDKRQVRHLVENWQEWVMKWMVKWDVQTRVKLMRDIPVGTLNPR

STV KDELQAFINAKILGYEQLGDKGKSRYLGVSWQQWVLRWIMKWNQRTRKRLLKNLPVGKLRRG

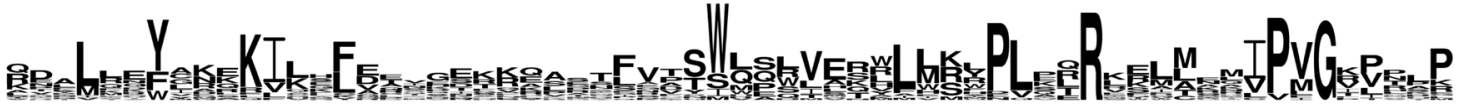

Fig. 4

Multiple sequence alignment of regions encompassing the +1 PRF sites of 25 amalgavirus ORF1+2 fusion protein sequences Predicted $\alpha$-helices are marked with a gray background. Three recurrent +1 PRF sites are labeled as \#1, \#2, and \#3, with arrows indicating the ORF1 and ORF2 boundary. Numbers of viruses are shown in parenthesis. The last residue of ORF1 and the first residue of ORF2 are marked in bold letters. Sequence logo representation is shown at the bottom. See Supplementary Fig. S1 for the full-length alignment. 
The three +1 PRF sites are closely located to each other within a 13 aa segment bounded by multiple conserved residues (Fig. 4). Distribution of +1 PRF sites among amalgaviruses indicates that these positions were switched repeatedly during virus evolution. However, only three positions within a short interval were recurrently used, implying that the ORF1/ORF2 boundary was highly conserved, which is likely the result of selection for proper folding of the fusion protein. Secondary structure prediction of 25 amalgavirus fusion proteins revealed that the +1 PRF positions were preferentially located within a random coil between two $\alpha$-helices, one from ORF1 and the other from ORF2, or near the tip of an $\alpha$-helix (Fig. 4). It is most likely that the $\mathrm{ORF} 1+2$ fusion protein position is under selection to ensure it does not interfere with proper folding and function of the fusion protein.

In conclusion, the full-length genome sequence of a novel amalgavirus CiRV1 was identified in the C. incanus transcriptome. CiRV1 is the first virus associated with any Cistus species (http://www.genome.jp/virushostdb; as of January 24, 2018) (Mihara et al., 2016). CiRV1 genome sequence may be useful for studying evolution of amalgavirus genomic features, including a +1 PRF motif.

Acknowledgments. This research was supported by the National Research Foundation of Korea funded by the Korea Government (grant No. 2017R1A1B4005866).

Supplementary information is available in the online version of the paper.

\section{References}

Bankevich A, Nurk S, Antipov D, Gurevich AA, Dvorkin M, Kulikov AS, Lesin VM, Nikolenko SI, Pham S, Prjibelski AD, Pyshkin AV, Sirotkin AV, Vyahhi N, Tesler G, Alekseyev MA, Pevyer PA (2012): SPAdes: a new genome assembly algorithm and its applications to single-cell sequencing. J. Comput. Biol. 19, 455-477. https://doi.org/10.1089/ cmb.2012.0021

Crooks GE, Hon G, Chandonia JM, Brenner SE (2004): WebLogo: a sequence logo generator. Genome Res. 14, 1188-1190. https://doi.org/10.1101/gr.849004

Depierreux D, Vong M, Nibert ML (2016): Nucleotide sequence of Zygosaccharomyces bailii virus Z: Evidence for +1 programmed ribosomal frameshifting and for assignment to family Amalgaviridae. Virus Res. 217, 115-124. https:// doi.org/10.1016/j.virusres.2016.02.008

Edgar RC (2004): MUSCLE: multiple sequence alignment with high accuracy and high throughput. Nucleic Acids Res. 32, 1792-1797. https://doi.org/10.1093/nar/gkh340

Firth AE, Jagger BW, Wise HM, Nelson CC, Parsawar K, Wills NM, Napthine S, Taubenberger JK, Digard P, Atkins JF (2012): Ribosomal frameshifting used in influenza A virus expression occurs within the sequence UCC_UUU_CGU and is in the +1 direction. Open Biol. 2, 120109. https:// doi.org/10.1098/rsob.120109

Goh CJ, Park D, Kim H, Sebastiani F, Hahn Y (2018): Novel Divavirus (family Betaflexiviridae) and Mitovirus (family Narnaviridae) species identified in basil (Ocimum basilicum). Acta Virol. (in press).

Isogai $\mathrm{M}$, Nakamura T, Ishii K, Watanabe M, Yamagishi N, Yoshikawa N (2011): Histochemical detection of Blueberry latent virus in highbush blueberry plant. J. Gen. Plant Pathol. 77, 304-306. https://doi.org/10.1007/ s10327-011-0323-0

Kim DS, Jung JY, Wang Y, Oh HJ, Choi D, Jeon CO, Hahn, Y (2014): Plant RNA virus sequences identified in kimchi by microbial metatranscriptome analysis. J. Microbiol. Biotechnol. 24, 979-986. https://doi.org/10.4014/jmb.1404.04017

Kim H, Park D, Hahn Y (2018): Identification of novel RNA viruses in alfalfa (Medicago sativa): an Alphapartitivirus, a Deltapartitivirus, and a Marafivirus. Gene 638, 7-12. https://doi.org/10.1016/j.gene.2017.09.069

Kondo H, Hisano S, Chiba S, Maruyama K, Andika IB, Toyoda K, Fujimori F, Suzuki N (2016): Sequence and phylogenetic analyses of novel totivirus-like doublestranded RNAs from field-collected powdery mildew fungi. Virus Res. 213, 353-364. https://doi.org/10.1016/j. virusres.2015.11.015

Krupovic M, Dolja VV, Koonin EV (2015): Plant viruses of the Amalgaviridae family evolved via recombination between viruses with double-stranded and negative-strand RNA genomes. Biol. Direct 10, 12. https://doi.org/10.1186/ $\underline{\text { s13062-015-0047-8 }}$

Larkin MA, Blackshields G, Brown NP, Chenna R, McGettigan PA, McWilliam H, Valentin F, Wallace IM, Wilm A, Lopez R, Thompson JD, Gibson TJ, Higgins, DG (2007): Clustal W and Clustal X version 2.0. Bioinformatics 23, 2947-2948. https://doi.org/10.1093/bioinformatics/btm 404

Li, H (2011): A statistical framework for SNP calling, mutation discovery, association mapping and population genetical parameter estimation from sequencing data. Bioinformatics 27, 2987-2993. https://doi.org/10.1093/ bioinformatics/btr509

Li H, Durbin R (2009): Fast and accurate short read alignment with Burrows-Wheeler transform. Bioinformatics 25, 17541760. https://doi.org/10.1093/bioinformatics/btp324

Li N, Li Y, Zheng C, Huang J, Zhang S (2016): Genome-wide comparative analysis of the codon usage patterns in plants. Genes Genom. 38, 723-731 https://doi.org/10.1007/ $\underline{\text { s13258-016-0417-3 }}$

Liu H, Fu Y, Xie J, Cheng J, Ghabrial SA, Li G, Yi X, Jiang D (2012): Discovery of novel dsRNA viral sequences by in silico cloning and implications for viral diversity, host range and evolution. PLoS One 7, e42147. https://doi.org/10.1371/ journal.pone.0042147

Liu W, Chen J (2009): A double-stranded RNA as the genome of a potential virus infecting Vicia faba. Virus Genes 39, 126-131. https://doi.org/10.1007/s11262-009-0362-1

Martin RR, Zhou J, Tzanetakis IE (2011): Blueberry latent virus: an amalgam of the Partitiviridae and Totiviridae. 
Virus Res. 155, 175-180. https://doi.org/10.1016/j. virusres.2010.09.020

McGuffin LJ, Bryson K, Jones DT (2000): The PSIPRED protein structure prediction server. Bioinformatics 16, 404-405. https://doi.org/10.1093/bioinformatics/16.4.404

Mihara T, Nishimura Y, Shimizu Y, Nishiyama H, Yoshikawa G, Uehara H, Hingamp P, Goto S, Ogata H (2016): Linking virus genomes with host taxonomy. Viruses 8, 66. https:// doi.org/10.3390/v8030066

Nibert ML, Ghabrial SA, Maiss E, Lesker T, Vainio EJ, Jiang D, Suzuki N (2014): Taxonomic reorganization of family Partitiviridae and other recent progress in partitivirus research. Virus Res. 188, 128-141. https://doi.org/10.1016/j. virusres.2014.04.007

Nibert ML, Pyle JD, Firth AE (2016): A +1 ribosomal frameshifting motif prevalent among plant amalgaviruses. Virology 498, 201-208. https://doi.org/10.1016/j.virol.2016.07.002

Park D, Goh CJ, Kim H, Hahn Y (2018): Identification of two novel amalgaviruses in the common eelgrass (Zostera marina) and in silico analysis of the amalgavirus +1 programmed ribosomal frameshifting sites. Plant Pathol. J. 34, 150-156.

Park D, Hahn Y (2017a): Genome sequence of Spinach cryptic virus 1, a new member of the genus Alphapartitivirus (family Partitiviridae), identified in spinach. J. Microbiol. Biotechnol. 27, 834-837. https://doi.org/10.4014/ jmb.1611.11026

Park D, Hahn Y (2017b): Genome sequences of Spinach deltapartitivirus 1, Spinach amalgavirus 1, and Spinach latent virus identified in spinach transcriptome. J. Microbiol. Biotechnol. 27, 1324-1330. https://doi.org/10.4014/ jmb.1703.03043

Pyle JD, Keeling PJ, Nibert ML (2017): Amalga-like virus infecting Antonospora locustae, a microsporidian pathogen of grasshoppers, plus related viruses associated with other arthropods. Virus Res. 233, 95-104. https://doi. org/10.1016/j.virusres.2017.02.015

Sabanadzovic S, Abou Ghanem-Sabanadzovic N, Valverde RA (2010): A novel monopartite dsRNA virus from rhododendron. Arch. Virol. 155, 1859-1863. https://doi. org/10.1007/s00705-010-0770-5

Sabanadzovic S, Valverde RA, Brown JK, Martin RR, Tzanetakis IE (2009): Southern tomato virus: The link between the families Totiviridae and Partitiviridae. Virus Res. 140, 130-137. https://doi.org/10.1016/j.virusres.2008.11.018

Schneider TD, Stephens RM (1990): Sequence logos: a new way to display consensus sequences. Nucleic Acids Res. 18, 6097-6100. https://doi.org/10.1093/nar/18.20.6097 


\title{
Supplementary information
}

\section{Identification of a novel plant amalgavirus (Amalgavirus, Amalgaviridae) genome sequence in Cistus incanus}

\author{
C. J. GOH ${ }^{1}$, D. PARK 1 , J. S. LEE ${ }^{1}$, F. SEBASTIANI ${ }^{2}$, Y. HAHN ${ }^{*}$
}

${ }^{1}$ Department of Life Science, Chung-Ang University, Seoul 06974, South Korea; ${ }^{2}$ Institute for Sustainable Plant Protection, Department of Biology, Agriculture and Food Sciences, The National Research Council of Italy, Sesto Fiorentino, Italy

Received February 2, 2018; accepted March 3, 2018

Supplementary Table S1. Sequence variation of CiRV1

\begin{tabular}{|c|c|c|c|c|c|c|c|}
\hline Position & Con $^{a}$ & Alt $^{\mathrm{b}}$ & Quality $^{c}$ & Con \# & Alt \# & Con \% & Alt \% \\
\hline 254 & $\mathrm{~T}$ & C & 103 & 8 & 7 & 53.33 & 46.67 \\
\hline 257 & G & A & 87 & 10 & 6 & 62.5 & 37.5 \\
\hline 272 & $\mathrm{C}$ & $\mathrm{T}$ & 49.474 & 10 & 4 & 71.43 & 28.57 \\
\hline 296 & $\mathrm{~T}$ & C & 69 & 19 & 6 & 76 & 24 \\
\hline 347 & G & C & 168 & 21 & 10 & 67.74 & 32.26 \\
\hline 350 & A & G & 176 & 20 & 10 & 66.67 & 33.33 \\
\hline 368 & G & A & 203 & 22 & 13 & 62.86 & 37.14 \\
\hline 398 & $\mathrm{C}$ & $\mathrm{T}$ & 222 & 22 & 14 & 61.11 & 38.89 \\
\hline 455 & A & G & 182 & 21 & 12 & 63.64 & 36.36 \\
\hline 458 & G & A & 187 & 19 & 12 & 61.29 & 38.71 \\
\hline 542 & A & G & 142 & 14 & 13 & 51.85 & 48.15 \\
\hline 602 & C & $\mathrm{T}$ & 222 & 30 & 25 & 54.55 & 45.45 \\
\hline 620 & $\mathrm{~T}$ & C & 222 & 36 & 27 & 57.14 & 42.86 \\
\hline 656 & $\mathrm{~T}$ & C & 222 & 34 & 23 & 59.65 & 40.35 \\
\hline 662 & A & G & 222 & 36 & 24 & 60 & 40 \\
\hline 681 & $\mathrm{C}$ & $\mathrm{T}$ & 222 & 28 & 20 & 58.33 & 41.67 \\
\hline 683 & G & A & 222 & 27 & 20 & 57.45 & 42.55 \\
\hline 713 & $\mathrm{~T}$ & C & 183 & 21 & 16 & 56.76 & 43.24 \\
\hline 736 & C & A & 177 & 20 & 13 & 60.61 & 39.39 \\
\hline 752 & $\mathrm{C}$ & $\mathrm{T}$ & 101 & 19 & 10 & 65.52 & 34.48 \\
\hline 795 & $\mathrm{~T}$ & C & 218 & 25 & 18 & 58.14 & 41.86 \\
\hline 815 & $\mathrm{C}$ & $\mathrm{T}$ & 222 & 29 & 18 & 61.7 & 38.3 \\
\hline 861 & C & A & 222 & 28 & 17 & 62.22 & 37.78 \\
\hline 863 & A & G & 222 & 26 & 18 & 59.09 & 40.91 \\
\hline 910 & A & G & 222 & 35 & 19 & 64.81 & 35.19 \\
\hline 920 & C & $\mathrm{T}$ & 222 & 35 & 22 & 61.4 & 38.6 \\
\hline 1049 & A & G & 199 & 36 & 16 & 69.23 & 30.77 \\
\hline 1103 & G & A & 222 & 37 & 22 & 62.71 & 37.29 \\
\hline 1109 & A & G & 222 & 31 & 20 & 60.78 & 39.22 \\
\hline 1141 & $\mathrm{~T}$ & C & 218 & 38 & 17 & 69.09 & 30.91 \\
\hline 1148 & A & $\mathrm{G}$ & 202 & 40 & 17 & 70.18 & 29.82 \\
\hline
\end{tabular}




\begin{tabular}{|c|c|c|c|c|c|c|c|}
\hline Position & Con $^{a}$ & $\mathrm{Alt}^{\mathrm{b}}$ & Quality $^{c}$ & Con \# & Alt \# & Con \% & Alt \% \\
\hline 1154 & $\mathrm{~T}$ & $\mathrm{C}$ & 176 & 35 & 14 & 71.43 & 28.57 \\
\hline 1221 & A & G & 130 & 25 & 9 & 73.53 & 26.47 \\
\hline 1232 & $\mathrm{C}$ & $\mathrm{T}$ & 114 & 23 & 8 & 74.19 & 25.81 \\
\hline 1238 & A & G & 134 & 25 & 9 & 73.53 & 26.47 \\
\hline 1247 & G & A & 126 & 25 & 9 & 73.53 & 26.47 \\
\hline 1248 & $\mathrm{~T}$ & A & 127 & 24 & 9 & 72.73 & 27.27 \\
\hline 1296 & $\mathrm{C}$ & A & 144 & 30 & 10 & 75 & 25 \\
\hline 1548 & $\mathrm{~T}$ & $\mathrm{C}$ & 93 & 44 & 9 & 83.02 & 16.98 \\
\hline 1584 & A & G & 96 & 34 & 8 & 80.95 & 19.05 \\
\hline 1599 & G & A & 103 & 42 & 10 & 80.77 & 19.23 \\
\hline 1601 & G & A & 109 & 41 & 10 & 80.39 & 19.61 \\
\hline 1662 & A & C & 147 & 59 & 17 & 77.63 & 22.37 \\
\hline 1678 & G & A & 171 & 57 & 18 & 76 & 24 \\
\hline 1839 & G & $\mathrm{T}$ & 124 & 41 & 11 & 78.85 & 21.15 \\
\hline 1899 & G & A & 216 & 47 & 19 & 71.21 & 28.79 \\
\hline 1911 & A & $\mathrm{T}$ & 198 & 48 & 18 & 72.73 & 27.27 \\
\hline 1917 & $\mathrm{~T}$ & C & 191 & 47 & 18 & 72.31 & 27.69 \\
\hline 1959 & $\mathrm{~T}$ & C & 169 & 41 & 13 & 75.93 & 24.07 \\
\hline 1977 & G & A & 222 & 44 & 19 & 69.84 & 30.16 \\
\hline 1980 & A & G & 222 & 46 & 19 & 70.77 & 29.23 \\
\hline 1995 & G & A & 222 & 47 & 22 & 68.12 & 31.88 \\
\hline 2011 & C & $\mathrm{T}$ & 222 & 40 & 20 & 66.67 & 33.33 \\
\hline 2031 & $\mathrm{~T}$ & C & 222 & 49 & 27 & 64.47 & 35.53 \\
\hline 2056 & A & G & 210 & 71 & 25 & 73.96 & 26.04 \\
\hline 2118 & G & A & 77 & 76 & 13 & 85.39 & 14.61 \\
\hline 2139 & G & A & 71 & 69 & 12 & 85.19 & 14.81 \\
\hline 2148 & $\mathrm{~T}$ & C & 96 & 56 & 11 & 83.58 & 16.42 \\
\hline 2187 & A & G & 42.5884 & 43 & 9 & 82.69 & 17.31 \\
\hline 2229 & $\mathrm{C}$ & G & 184 & 34 & 13 & 72.34 & 27.66 \\
\hline 2232 & $\mathrm{C}$ & $\mathrm{T}$ & 189 & 32 & 13 & 71.11 & 28.89 \\
\hline 2244 & A & G & 202 & 36 & 15 & 70.59 & 29.41 \\
\hline 2265 & $\mathrm{C}$ & $\mathrm{T}$ & 197 & 39 & 15 & 72.22 & 27.78 \\
\hline 2307 & G & A & 221 & 55 & 21 & 72.37 & 27.63 \\
\hline 2312 & A & G & 206 & 62 & 21 & 74.7 & 25.3 \\
\hline 2382 & $\mathrm{~T}$ & $\mathrm{C}$ & 204 & 51 & 18 & 73.91 & 26.09 \\
\hline 2514 & G & A & 222 & 46 & 21 & 68.66 & 31.34 \\
\hline 2562 & $\mathrm{~T}$ & $\mathrm{C}$ & 222 & 42 & 21 & 66.67 & 33.33 \\
\hline 2676 & $\mathrm{C}$ & $\mathrm{T}$ & 218 & 66 & 23 & 74.16 & 25.84 \\
\hline 2763 & $\mathrm{C}$ & $\mathrm{T}$ & 222 & 61 & 32 & 65.59 & 34.41 \\
\hline 2840 & $\mathrm{C}$ & G & 219 & 51 & 19 & 72.86 & 27.14 \\
\hline 2892 & A & G & 222 & 24 & 20 & 54.55 & 45.45 \\
\hline 2935 & G & A & 222 & 25 & 17 & 59.52 & 40.48 \\
\hline 3030 & $\mathrm{~T}$ & $\mathrm{C}$ & 149 & 19 & 21 & 47.5 & 52.5 \\
\hline 3060 & $\mathrm{C}$ & G & 126 & 35 & 20 & 63.64 & 36.36 \\
\hline
\end{tabular}

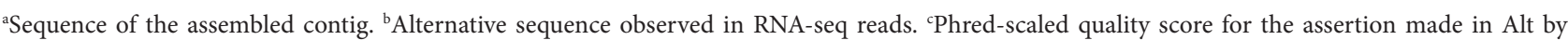
BCFtools 
Supplementary Fig. S1. Multiple sequence alignment of ORF1+2 fusion proteins. The first amino acid of ORF2 part is highlighted in red

CiRV1 - - MPVDPLRYMDSQVD--LEGEEAEAMGKLWEPFATSQLTRKDCSYADLLEMSATLGDFEKCVKAVRSFLVQEIFDDLWSKAHSAGVVASAQTLTLQSLFRF CIRV1 $\begin{array}{lll}\text { FpAV2 } & -1 \\ \text { FpAV3 } & -1\end{array}$

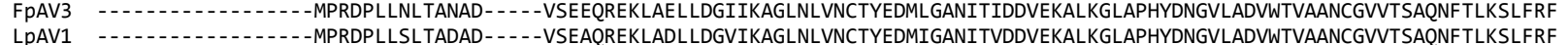

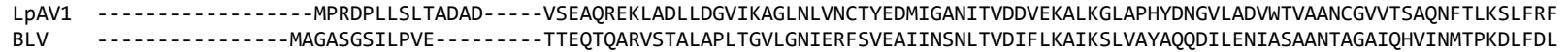

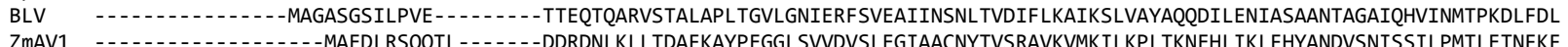
ZmAV2 - - - MFFREKMANEDGSSVPLKTQAQV--DEERDVAQLNKALSYLDLGGMPIAPWALQDVADCSYTVARALRKLKILKPHYDNKHLQKLFHYCEENAVIDSTLPLKLSSVFRF ACAV1 - 1 - MSAEDFTPRTGLVDTELLVDPAAELEELHDALMPLEVLNINVKAFTRANIFALRMTVPOYIKEVRVLONLODVQL IRKVWTEAISHKCATLPDEADAGVCLSF ACAV12 -

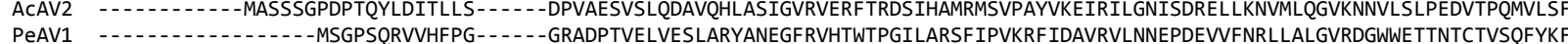
SCAV1 -MSETSGNSGTESEKMERIRKELADQENLEL-- - - - TLEEQQAEMDKLVPPFRARHIPEEIFNVEQAQLDGHSFKNYLKLVKTVHNLEKDGHLGKAISKGGALGFWELYTEMTRAEFVKF SpAV1 - - EbAV1 - EbAV2 - COAV1 -MANAGGN-- - -GAPRPVOPLPQPPVYYFGOH-- - TPAENQARITEAVTFLAOCGVNVGLFTVDAVNOVGMTTDQFIKAVKPLOTHAEOGVINPLFTEAIRARVFDVVMELNVQOVVNV GaAV1 -MSHSEEEVRVEFGPIDRTAAAAGPSAQLHGTT--- - TEREAQEEVTRMVQPLRNQGLNTEVFTLASIYDVGLTGDGFCKLARGFLSITDEDIQESLLLAGQKKGKLGPLRRVSVREFVDF CdAV1 -MAEHQDP----QQQQGGAVGGDVEEVNLLEGIGGIPTAAEERNRLQEALRPLIANGVNIERITVNDCLRLGFTVEQLARAIRVLTSIASDEMRDLIFSQAHLSRLAPAARSVTLDHILA MSAV1 - MADFEAQRDDNIAANAPIGGLSSKQQEIDTVTAAITPLLAAGFPQAIFNYDDLLLRGYTAKTFCDFIKPLSAITERRELISLCALG-NNRFWDMSVVAELDEFLNF VCV-M - - MAQFETSDPANVGEGAGIGGIRSKAEEQATVNOAMNAIVRLGFPEDIFDIDALLERGFTAKSWCDYCRAITSITERRDMSALLALG-GTRFWELPIDATLENFIDF RHV-A MEDRRAEDRLDDDLPAGGGAPPPLRGLPPLPRAEP - -TDAELOAAIDEAVAVVYEAGMPAGRFTVORVHEIGLTVEVFVKOARAVFGGKNVDOADLIFTTGIKMGVCGSLRTMEPAGFWEV AOAV1 - - - - MAEPRRTFOTAAPTEGDYVANLPADEDAAFVYFARWVFTTYHLAAGLLDPATYRPEGYSDKDMAARLRFFKG-KEADVIDTIFAVGVRKSFFTAKESATFEOFANF FpAV1 - - CaAV1 -MSGTSGP---_-RTPGSSGVKTVPLTARE---KEIAMIEEIDEIGVTFIELGVSAAFFDSRVYTKNLLLPAQYLRLLRQFKG-KDAGEVELIFSAAIAKKQVRASRGIGWNKWIQF STV -MAGVGGS--.---AAGRVPNAANVPLTAKE----KERTVMREIVEIGETFVELGIDKRYFQRTTYVSHMLLPNQYFKLLKQFKG-KTAEELDLALGAAVAHGVLRSMRGITFKKFFDF PpAV1 -

98 98 98
98 96
95 95
108 108 103 103 97
114 101 96 96 100 111 116
115 105 105 105 119 105 105 107
107 88

CIRV1 RNWITKPAGQGVLAVQNKKKLVRAGGDVFLPDQIALLRLFQHQVDVRSREAKVVQEKRDKRLAELRLEMENVKQAAEDKLARIDRRSRPTSAYVPVDPIELRRLCWVEYVKDCNKRGLVP FPAV2 RRWLTTPQGAQALSLVQARRKMTKAGKKVLGHQDVALLRLLQHYEDDARRELDAKRVETEAAVAQLQAEIDKLKKKYAKAEKKQKRDFPLIANYVPLTDNEVRNQAWDMYCQQCINEGSV FPAV3 KVWITKDQGSTALRQAQQKAKLAKAGKDAFPADEMTLLRLWKAQQDDMQSFVKRERVPIDAKIASLRAKIVEQEELLEAKKGEEMMKYPLLSAYVAPDLSELRDLCWKVYLQICNSEGKEV LPAV1 KVWITKDOGATALROAOOKAKLAKAGKDEFPADEMTLLRLWKAOODDMOSFVKRERVPIDAKIASLRAKIVEOEELLESKKOEEMMKYPLLSAYVPPDLSELRDLCWKVYLOICNSEGKDA BLV SRWVKTAAGMEAISKITTORRLLROGGAGRSASOVAWVNLFTOOQADYAOEKKRKMTRFERKREDLKLOLAOLDTDEAASMERLAAKYPTOVALPATMETELVAACWAAYVADCDRRGITP ZmAV1 CKWLTSPVAKKKIAALQNADRLRRRGSDVVTPEEAAMIALLESAQADRTTEYSKARARYDIDVAKYKKKIAKRTRQLEEDLDKVQASYPGLOLIERPDEHSVMASAWHRYVDFCTSNNFEV $\begin{array}{ll}\text { ZmAV1 } & \text { CKWLTSPVAKKKIAALQNADRLRRRGSVVTPEEAAMIALLESAQADRTTEYSKARARYDIDVAKYKKKIAKRTRQLEEDLDKVQASYPGLQLIERPDEHSVMASAWHRYVICTSNFEV } \\ \text { ZmAV2 CDWLLSPVAKRKIEOLVNADRLKKRSRDAITPAETALVAILEVAONDCVADVSRVRITYVEEIKKLKRKIGKLEEHKARKIEKARKKYPGLLLLERPSESDVCNQAWHKYVEYCNASGIKO }\end{array}$ ACAV1 ARWLKRGVGAKVLSDAQHLIKLQKRAVGSVEPKVLAFVQLLDQQIADMHAERKKIQAEGQAKIDELRREIQRVEREYDEKAKASSKRFKPARKYVPPTKAKIDEECWNAYLNKVQKSGKTA ACAV2 ARWLKRGAGARVLADQQHLLKINKKAVGDSTPDIVAFAHLLDQQVQDLTNAKKRVQHSSQVRIDELRKQIAIEEHNLRRDLAATARQFTPANDYAPPSKAALDNECWELYCARARDAGRA PeAV1 CNWLKSAEGTTRLNEIRKARHLEKKAOPGOTLEDVSLVAALDEOVAEFOORKKETRLEFESKLIDLRROIALVOOEMSATMKAHDADFSPASIYEPMDDLEFGEACWNLYRAECARLNODE SCAV1 ARWLTSTEGVDFVFGLQKMKKYTSKAKDSVTPRQIAISGVFTHMLQKYSSEVKETRSKYDKEIARMERELRLKRKEKEREIGKLIDQYKPASLYVPPKDEEVGLVARELYEADCERKGKAK SPAV1 ARWLOSKEGQDEIYTLOREOKLLRKAGESLTPTOMIKNDVFNL IRTEFSRAMKAEREKFEOEKDELRRLLROKEREEROAFKNLOEKFAPISFYREPTDEEVGIAAYEMYENEARKNGKTP EbAV1 SEWLRSKDGONSLHEVORHKKLEKKAAGVLEPREVALEOIFSAORADWAAAKKEERSAYPKEIOELRKKIROLERRWERREVEIDNAFDPOFEFLELDEAALNERAYAMYVHDCOVKERRP EbAV2 GAYLKTTKGQEALHGAQKMKKYQAKVIGEFEPKDVVLEQIFNAQRADYAEVLKEERSNYDREIEALKKQIRLLEARKEERLEQIAAGFAPASYYSEPDPADVAVEAWEMYQNDARAKGKVA COAV1 CEWLKSRGGQNAISTVYRTRKLQAKVLPGTTAADVAWASVLQQQLSDLSGKRKEIRVEKDEAIAELRREIQRLEIEKGLDLAAIDAEMVPASMYNELNAAEIARRSFNLYTQRAALQGVV GaAV1 LKWLKDTGGQAEARAIHROGKLKKKASEGOSAEDLTLLOVFNLMLODMSOAIKKERSIRDEEIYALRSKMRRLERORDAKILEIREEYSPASNFKEPESDEVGRLSYDIYVORAKEAGHTW CdAV1 CEWMKTERGAQAIRNLQTSAKQERRAVGGRTVADVSMLQAFNQQVADWSAQVKEARKEIEEEMAELRAQLALKQQELNDSLAAINESYWPASSYKAPALNVVQSQAYALYAADCRRSGTVP MSAV1 VKWLKSPEGRDAOTOAAKKRALNKKASDGMSTKDVALVOMGNAIIADYORERKORRFPIEEEMAELRROLROLDEELOAVEEEIKVKYGPVALYEGPDNTRVKSDAYLMYODDCRKKGYRA VCV-M VKWIKSPEGRDAOTAAAKKRSLOKRAVGGLSTADVAIIOMGNSMIADYOKERKKARAPIEEOORHLRRELRLLDDELAATELSVKERFGCIATYEGPDNHTVSREAYKLYLEYCRENRVRA RHV-A IRWARSNVGRQALETGQKVKKVEDKRAGTQTPNEVALCQIFTMQQGIMAEEVKEARASTQQEIDELTRLLRLKRAEQVKVLAEIKDKYFPANIWEEPAEAERNARCWEVYSAALVTAGRPA AoAV1 LEFLRTADGAAAVTEDLRRSRFQAAGKGVFNAVEISSVAQLTVQLADLELHKHRMSDASQKRIDELELLIAKEKESLETKLKMSDEEFFPASIYKKLNPMKLQKECWVRAKASSTELAAVA FpAV1 LEFLKTPEGASAITEDLRRARFLAAGKGVFTAVDIAAVSQLTVQAADLEQHKARMIAASQKRIDELELAIAKEKESLETKLALSKDEFFPASIYKKPNAMKLQKECLIKAKAADPVLSAVA CaAV1 LNWAKSPAGHKAIOEVMNIEKLERRGGGDFTVDEVAALNLFDVORNDWIGHOKEARAIAEHEIAELORKINLRRDKLDEDLREIADOHRPVSGYVPLTDAELNLRCWNFFROAHEGVRGVG STV LWWKTKEGKDALGETMYAQKLEQKGRGDFSIAEVALLHCFETORNDMLRDEKDVRLKAEEEIADLORKIVKRREKLEEDLIATKSNYEPVSRYVGLSDYELNCKCWSLYQOFNPDKVTAG PPAV1 ARWCKDKDNRDALAQAQKVSKIRRKAGASLATDDVAFVSLFDQMYADWSHAAKEVRVTHERRIQELEAELRIVRQRLAVALEENALAYRAVSSFRAPNEEEFVSRCVDKWLATFIGTPPAR

CIRV1 HPKSELNLEAATERFNAEVRQRHQLEFALTPGNKEKLLSFGRKELKKFEEKNERRQASTFVPQSMSSLESRLLKYPLPTRMKLMKRIPVGIPRAK-LSKIRTKP-LMTVLKSRLLRQRVVV FPAV2 MGRTSTNLKIVGDKFRDHIVQAHKLTYCQQPDHTDALIEFGKQKILRCQEAGSGKLESSFVTYSLSSIQRMLLRYPLAQRKQMMEWIPMGVVPTR-PSLTRTQM-LSQLPTNPLLLKPRVL FPAV3 FPKNEDNLRLVEEKYKELVLNRHLANFLRLPONKNAMLNYGKLKIKKLEESKSKRELSTFVASSOSLIHRVLMSRPLKORKELMAAIPMGVPTLP-LSOISTVP-LSSLOLORDLMMSRTV LPAV1 FPKNEENLRLVEEKYKELVQNRHLANFLRLPONKNAMLNYGKLKIKKLAEGKSKRELSTFVASSOSLIHRVLMSHPLKORKEMMAAIPMGVPLLP-LNQITTVP-LSSLOLORDLMMRRTV BLV SAKTNASLTEAVKHYSANVRDQILTTYCEQENVQADLTRYAREKIQSFVTQETREESPVLEISIRQQLEQRLISLPLELRKFHMKQVPFGIPLHK -RGRPSCKP-LLTKLSPELLLRRTQI ZmAV1 PQKNDGNLARAYKQFERELTLEIKNTACQKPEVRDYLLQYCKEKVKGFVPNSKTKELKLIGDTMHARLETYFLRIPLERRGRLLDQIPVGRLTRK -GKMTPNIP-LSQIFSTPALGMTAVH ZmAV2 EKRSNASLEKAISMFDNILRLEIKAKCCEKPEVRDYLLQYCKEKIKGFVTTPIKSALTHSRDTILQRLESHFLKAPLERREELLPLIPVGTVNPM-GHLNATMS-LREILWTESLKNRQV E ACAV1 PEWNAVLQEQANTMYOQLYLTQHKQDFCGLESNQIPLKVWADSKLKELADNHEFVASARPSESWVSRVESHLHRLPLPORVFOANNVPVGPVSOLVMNOSRNMA-LRTLLNPOLLTWKSQI ACAV2 PPWNAILQEQATTALSNEVINKHRQDFCKIPSNQRLLQTWAASKIQDLRTNQEFVASQSSNDSWLSQVETHLWRLPLPLRLKWANTIPVGKVVSR -KRRNGNIL-LRSMLGADLLNNPMOR PeAV1 APLDDGLLEAVKLTHGNAALAMHKANFLRVGFNRNNLKHWIEEKILELDTVGEARRATTFVPTWOORVERWLMKFELKLRLELLOOVVLGVPCAE-PGTRLTLR-MSNLLDFGLVLRREIL SCAV1 1 KTVATGLLEYAKQLFGQEARNRFEIAFASKEEYQDALMKYLAEQVCLFEATQTTPRPEMENTTWLSLVESRALSWPLPQRKSVLGIVPLGRPPLP-HQRPQCRP-LCQIINPEILSNPROE $\begin{array}{ll}\text { SCAV1 } & \text { KTVATGLLEYAKQLFGQEARNRFEIAFASKEEYQDALMKYLAEQVCLFEATQTTPRPEMENTTWLSLVESRALSWPLPQRKSVLGIVPLGRPPLP-HQRPQCRP-LCQIINPEILSNPRQE } \\ \text { SPAV1 } & \text { MSRYHGGDVYARQHFSQAARELAQVYFASNPENQDIMERFMKERFLFFGRPPMNLGSAQQECSWLALVERKLWKMPLRRLRLTGMIPIGILQAP-GRRGRCRE-LRRKLSPDLLASPRQV } \\ \text { EbAV1 } & \text { RSKEHGGVOLAVEAFGGOVKKOKOAEFAREPEVAVKLFEYAKRKILSFEEMVTSNRKPIGKFTWMPRVETYLLSRPVKLRKRICSMCPVGLPPPP-GVAPGCOP-LSKFVREELLVSGVVE }\end{array}$ EbAV1 RSKEHGGVQLAVEAFGGQVKKQKQAEFAREPEVAVKLFEYAKRKILSFEEMVTSNRKPIGKFTWMPRVETYLLSRPVKLRKRICSMCPVGLPPPP-GVAPGCQP-LSKFVREELLVSGVVE EbAV2 MSRYDGGDKYAVANFGNKVKRLHCLEYCGDDASRTLLLEYCKKKILAFGPIRISDKPHPSRVCWLEQVETWLLSRPVALRREICSLVPVGFPHLP-QQRPECFE-LSSLVSRDVLERKNQL COAV1 LPRNDDGIKMAVDLFGNEVRQRHMQEFVQGEVVQQQLMQFLRGKILELDQIHERKQASTFVPYWLQSVVRRLHSRPLQRRLEMMEMIPVGKPNKP-GENNVRMP-LSLFLPEWLKSEKGQL GaAV1 LPKNAAGLKAARDLYGOEVRNROMMTCAAVPTARPLMFEYLRKKILOFDAAADTKOAETFVTTWOOLVAOALMRHPLVEROKLANLVPVGRPPLP-GTLLGTWP-LRRNLSPDILKEAROS CDAV1 LPAGSLGYSKAVELFGOOVREDHOLOYLRAEEARDTLSEYLORLVGLKAGOGRRREVENFVPSWOEWVSOLLMRYPLERRRWLLNRLVVGRINPP-GREPRTRL-LREVMPAELMKAKROA $\begin{array}{ll}\text { CdAV1 } & \text { LPAGSLGYSKAVELFGQQVREDHQLQYLRAEEARDTLSEYLQRLVGLKAGQGRRREVENFVPSWQEWVSQLLMRYPLERRRWLLNRLVVGRINPP-GREPRTRL-LREVMPAELMKAKRQA } \\ \text { MSAV1 } & \text { IAQYQGGFEKAVELFGNKVREAHFCAYLSDPARSDFVRDYYNQKIVHLERSGEKKQAGSFAVSWWWPLMEKWLLMFPLSTRSTLMEKIPVGKVHKP-GETPTNRP-LLRGADKSRVLNVRQS } \\ \text { VCV-M } & \text { IASHQGGFDKAVEMFGAKVRETHFRDYLLDATRAEFIRDYYNOKVLHLDRSGEKKOAGTFVTSWWPDVEKWLLMLPLSORLSLMEKIPVGKVPSP-GQLPENQP-LRRSVEGPLVLEKOQQ }\end{array}$ VCV-M IASHQGGFDKAVEMFGAKVRETHFRDYLLDATRAEFIRDYYNQKVLHLDRSGEKKQAGTFVTSWWPDVEKWLLMLPLSQRLSLMEKIPVGKVPSP-GQLPENQP-LRRSVEGPLVLEKQQQ RHV-A PIKTEAAFKLAIDAYKNFVDTEFKTRFIRSDEHQVALRKFADERIHFLDGIGEPKKAGTFAASWQSSVLNLLLRQPLIRRREMMRMIPVGKVMLP-GERSQNLR-LEEVLVDPVLLEGVQA AoAV1 VPTND-QLADALKNFKEEVERRHAVDFLAQQNRLTALREYVNKKILSFVLVENTGSRPALDTSWLPWTAKLLEKYPLPERISATAMIPMGRTTSP - TTSVSCRTNLLEVMRSPALLAVRQR FPAV1 VPTNE-OISDALKOFREEVERODMVTFLSOQDRLHRLREYVGKKILSFELVESGRYPIDLSTSWLPWTASLLMKYPLSERVSATIMIPMGTITFP-SMSLKIRRNLLEVLKVPGMNRRKIL $\begin{array}{ll}\text { CaAV1 VHPTMSQMKEAFDTYSVHVAKRARVEYMRHGDHVPLLQEYINQKIAHFDAVGDKRQVRHLVFNWQEWVMKWMVKWDVQTRVKLMRDIPVGTLNPR-GNQTLCSR-LSEQIPMNRLLEKRVI } \\ \text { STV } & \text { AKPTRKQVKEAFDMYAEFVAKTNRLEFLKHGNVKDELQAFINAKILGYEQLGDKGKSRYLGVSWQQWVLRWIMKWNQRTRKRLLKNLPVGKLRRG-KEMTPCRP-LSEIIPMERLEEKRTL }\end{array}$ $\begin{array}{ll}\text { STV } & \text { AKPTRKQVKEAFDMYAEFVAKTNRLEFLKHGNVKDELQAFINAKILGYEQLGDKGKSRYLGVWQQWVLRWIMKWNQRTRKRLLKNLPVGKLRRG-KEMTPCRP-LSEIIPMERLEEKRTL } \\ \text { PpAV1 } & \text { AALTSANLEVACTTYGAEVASEWKAAHCRTPDVREALQNYCMRKIKHFEQESNEKQARNFVPSWMQLVSQRLWRLPLSTREREARGIPVGVVRLP-PLAVRSKP-LWQLISQELKSSLRQV }\end{array}$ 
CiRV1 GTRIKPPVARNLELMFDPLSLLATCKRVRLFGELGQVPKRAIATARSKWEAGVRHIIGGGELRTWRADNNMYRGGGNLHDAILLLGDADDTSDFIFLSSRLSLADARGILHLPVDLPVPDG FPAV2 GARPGPPLPKAVEAISGNSLLSTPNRRIOIHRRSGOPGQAGIPTARSRWEAGVRHIIGGGELLEWRVDNNKYRGGGNLHDALLLIGSADDVTPYTALSSLLSVEEARRVLLLPDGLAVPDG FPAV3 GGRPGPDLOQAIESCVTSFGLIRANKRLRVHRERSGLROISIPHARSKWEAGIRHIIGGGEILNFRADNCKYRGGGNLFDALTLLARADDTTEYSTLSVHFSVEQARHVLRLPSGLPVPDG LPAV1 GQRPGPDLRQALESCVSSFALLRKNKRLRVSRERSGLRQVSIPHARSKWEAGIRHVIGGGEILNFRADNCKYRGGGNLFDALTLLARADDTTEYSTLSVHFTVEQARHVLRLPSGLPVPDG BLV GHREKPPLGIRTELAQPPLKALEDCSRIGVLRSLAPQADKLIPRSRSKWEAGVRKIIGGGELKDWFKAKSMYRGGGNLFDALRLLSACDDYDGYTRLKGNYSVEAAREKLLLPSGLRVPDG ZmAV1 GTKPTPPIQRNLEMTLLPMNLLKTNLRVQLLTEHVRGGVRQISIARSKWEAGVRRIIGGGEMRGWEKDSALYRGGGNLHDAIRLLATGRQDPPGSFLFEHFSLETAREILLLPCNLEVPDG ZmAV2 GSKVKPPLPRKLEMLILPMNLLMANPRVNLLHAFVHASGRGLKIARSKWEAGVRRIVGGGEMRGWNEDSAKYRGGGNLHDAIRVLATGRHDLPGSFLFQHFNFRSARSILKLPSDLSVPDG ACAV1 GMRKKPPLOKANESRSSKIDLLLRNPRILVLRKPERGPLGGIPTARSKFEAMVRKVIGGGEMLNWSIDSNMYRGGGNFTDALTLLADARYDAPEMFLSDYLSIEKARSLLCLPSDLKVPCH ACAV2 GIKNKPPLARNAEVSASVTSLLDINARILVLRSIERSPTVGIPTARSRFEGAVRKVIGGGEMIDWRTVSNQYRGGGCFSDAILLLADARTDEPGKFLPDYFTLWKARDILRLPSDLKVPCN PeAV1 GSKQPAPLSSEIERAVLIPPLLWQNQRLSILRPLRPDLGGRIPHSRSRYEAKVRKVIGGGEMRDWRAANAMYRGGGSFSDALKLLIDAREDAPGAILSEKWKVDSARRYLLLPCGLPVPRG SCAV1 GVRPSQDLHPDLELKRPKPTLEE -NMRLRVVRSGPGEDRRRIPVSRSGYEGAVRKVIGGGALRSWKQDQAMYRGGGNNVDALLLMSQASEKRPGAFLRDRYSVLSARRALGLPSDLQVPDG SPAV1 GVKLQQGISRKVELTSLGPKMLR-TSRIRVLRSLGPERPRAIPVARSRFEAGVRKVIGGGAMRSWEVDSQMYRGGGNSADALRLLGQARDDRPGAFLSGKFTQASARLALLLPNNLDVPDG EbAV1 GTKKTNPLLRAFATVQLGAEVLR-STRVLVHHTFGPETQRRIPVARSRIEAGLRRIIGGGAMRGWDADSKMFRGGGNSSDALLLLGOCDDNLPGGLLREHFSLLSAKRALSLPGGLRVPDG EbAV2 GHRPIOVLARGIRAOELDSSIMR -NPRLKVYVNFOGEPGRVIPHSRSKYEAALRRIIGGGAMRSWGEDSKMYRGGGTSSDALLLLSOADFRLPGGLLKEHFSLRTAREALCLPEDLVVPDG COAV1 GIKVQRGLRROIEVVEGVASEEFRLVRGKVYVEWAAEKARLLPVARSKFETGVRRVIGGGEMRNWHVASSMYRGGGNNADALRLLSNASFMNPEKYLHECFTIETARRELLLTTDOKVPDG GaAV1 GLKGRPELGRGFELQGGLGSEALLTGRIKVLVHFEPERVRSMAVARSKFEAGVRKIIGGGEMRGWRSASSMYRGGGNSNDALRLLSOAKDDFPGRFLTDVFKVDMAREALCLESDLAVPDG CdAV1 GIRHRPGLQRKIEEAGGGSRGAEMTGRVRVLVEWGRERHRTIPVARGKFEAGIRKIIGGGELLNWREDSSMYRGGGNSADAIRMLFSADPIPPGRVLTDFWREGSARQALFIEELFEVPDG MSAV1 GYKSISRLERKHELQGCITSQGMPEGRIKIFKSWESEPGRMIPMSRSKYECAVRWVIGGGEVRNWKVDSSMYRGGGSSNDALKLLANASTVRPGKLLRDVYSFRVARARLQLPGDFSVPDG VCV-M GIKLTRGLORNVEMKGTLPSOSLRGRRIRILRPWVTDHNRMIPTSMSRYEGAVRWVIGGGETRRWKEASTMYRGGGCSNDALKLLANVSTVLPGRLLRDLYSLRVARARLSLPADFCVPDG RHV-A GVKGNARLSRNVEVSAQVRLGELQTYRFRVHREMVEHRVRSIAVARSRFEAGIRRIIGGGEMRSWYTDSRMYRGGGNSNDAMKLLSAASVVTPGKFLDQCYRVSSARKALRLPSGLRVPDS AOAV1 GTGPPPRLGAGVPAAVGTTPVLOGGARLHVIRAPVRPDRRGIPYARSKWEAGVRKIIGGGELSDWQAASSKVRCGGNASDALLLLADASDRLPGKTLRGLFTLRGARDALRLPSGLSVPDG FPAV1 PSSAPSRLGASVPRAOGVAPLLOGGARLRVLRAPVAPDTRGIPFARSKWEAGVRKIIGGGEMNDWLOVSSKERCGGNASDALLMLADASDRLPGRILRGLFTLRGAREALRLPSGLSVPDG CAAV1 SYRPAPQLSKMLECKAESLALLRANGRVEIIIMPGGCDLRAIPCARSRWEKGIRKIIGGGEMLNWKVAGNMYRGGGYSDAIKLLSSASTIPPGRLLHQCFSLPGARAALGLPSNLSVPVG STV QYKLPPQLSRATEVEAEAVSLLYPNARIEVEVRPIGRDTRAIPFSRSRWEVGVRKVIGGGEVLNWDIDGNKYRGGGCFADAIKLLAGATQRPPQRLLEDCYTITTAREALGLPSDLAVPSG PpAV1 GMRKVGKISPQMHNLVPSLSLFQGNGRLDVLRDVGSGKHRGIPTAMSMFEKGVRKVIGGGEMRDWNRASNFVRGGGDLGDALKFFSSCKTSPQQRFLCDVYSLEVAREILDLPTGLPVPDG

CiRV1 PKACVMKYFNEDATGGPLLRSGGVRRKYGLKSVIEEFVWNIYDAVGYGELTVDOLPGMTSRVGYRSKLMTTDKALDKITRAKPLGRAVMMLDATEOSFSSPIFNVISGIVSOLNRDPSTGW FPAV2 KACCVMKQFNDDATAGPLLRAFGVKGKYGLKAAIEQFVWGLYDRVGSEDLKPRQLPGLLARVGYRTKLLDMEKALKKIQAVEPLGRAVMMLDATEQCFSSPLFNAISEAVTELHSNPRSGW FPAV3 AQCCFMKQFNDDASAGPLLRAFGVKNKYGLKSMVESFVWGMYDRVGSDLTPDQLPCLLARLGFRTKLVDKDKAAKKIFDVEPVGRAVMMLDVTEQAFSSPLFNAVSEQVTLLHNDPRSGW LPAV1 POCCFMKOFNDDASAGPLLRAFGVRNKYGLKSIIEFFVWGMYDRVGAGTLNPEQLPCLLARLGFRTKLVDKDKAAKKIFDVEPVGRAVMMLDATEQAFSSPLFNAISEOVTFLHSDPRSGW BLV VGCVHMKNFNDEASAGPLCRAFGIRRKAGLKSRLEOFAWEIYDGIGNGDLDLGAIPPFLARVGYRTKLVTGEKAMRKISTGDSIGRAIMMLDAYEOAFSSPIFNVISDAVTHLHSDPTSGW ZmAV1 PKAVRMKNFNEDATAGPVLRALRCKSKYGLKEGLERIAWDLYDRVGDGKLRRWOLPPLLARIGFRSKLVEOESAIKKIFSGOPIGRAVMMLDAMEOPFSSPLYNALCDVVSKLNRVPESGW ZmAV2 RDSVTMRNFNEEATAGPVLRAIGCKTKYGLKRGLEDIVWNLYDRVGNGELRTWELPPLLARIGFRSKLIDQDKAEEKILTGQPLGRAVMMLDASEQAFSSPLYNVLSGVVSRLNCERRSGW $\begin{array}{ll}\text { ZmAV2 } & \text { RDSVTMRNFNEEATAGPVLRAIGCKTKYGLKRGLEDIVWNLYDRVGNGELRTWELPPLLARIGFRSKLIDQDKAEEKILTGQPLGRAVMMLDASEQAFSSPLYNVLSGVVSRLNCERRSGW } \\ \text { ACAV1 } & \text { RNCVSVNNFNNEATAGPFFRAHGIRNKYGMRLOLEDFAWECYNAYVDSGGNPSMLPYISSRVGFRTKLVSTTEAFAKMKDNKPIGRCVMMLDAIEOMFSTPLYNVLSKTTAAORFDIKSGF }\end{array}$ $\begin{array}{ll}\text { ACAV1 } & \text { RNCVSVNNFNNEATAGPFFRAHGIRNKYGMRLQLEDFAWECYNAYVDSGGNPSMLPYISSRVGFRTKLVSTTEAFAKMKDNKPIGRCVMMLDAIEQMFSTPLYNVLSKTTAAQRFDIKSGF } \\ \text { ACAV2 } & \text { ROALKVSNFNNDATAGPFFRAYGIKSKYGMRGLLEDFAWECYSSFVDNGGDVSFLPFVASRVGFRTKLVSSEEAFIRFSKNKAIGRCVMMLDAIEOMFSSPLYNVLSKLTADLRFDPASGF }\end{array}$ ACAV2 RQALKVSNFNNDATAGPFFRAYGIKSKYGMRGLLEDFAWECYSSFVDNGGDVSFLPFVASRVGFRTKLVSQEEAFIRFSKNKAIGRCVMMLDAIEQMFSSPLYNVLSKLTADLRFDPASGF $\begin{array}{ll}\text { PeAV1 } & \text { PEATKMKNFNDDATAGPALRAFGILRKSGLKTSLEEFAWNCLDAFARGGAAEDCLPFVAARVGYRTKLLTLSDAWSKINSCKPLGRCVMMLDAHEQAFSSPLYNVLSNLTHLSRFQRNSGF } \\ \text { SCAV1 } & \text { PAATKMKNFNNDATAGPFLKWCGVKSKRGLKCLLEEEMWGYYDAYAKGEIEDHOLPFLTARLGFRTKLLKKAEAMRRIGEGKAMGRAVMMMDALEQAASSPLYNAVSHYTFERRLEKDCGF }\end{array}$ $\begin{array}{ll}\text { SCAV1 } & \text { PAATKMKNFNNDATAGPFLKWCGVKSKRGLKCLLEEMWGYYDAYAKGEIEDHQLPFLTARLGFRTKLLKKAEAMRRIGEGKAMGRAVMMMDALEQAASSPLYNAVSHYTFERRLEKDCGF } \\ \text { SpAV1 } & \text { AKSTRMKNFNNDATAGPFLRSFGIKGKYGLKRKLEEEMWRYYDDYGAGRIDSSGLPFFTARVGFRTKLVSVEKAEEKFKTGQPFGRAVMMLDALEQAAASPLYNVLSHYTFERRLRRDCGF }\end{array}$ EbAV1 PECLVMKNFNNDATAGPFLRAFGIKGKYGLKKLLEDTMWWFYDAYGRGEISDGEMPHFAARVGFRTKLVSETKAWEKLAAGAPVGRAVMMLDALEQAASSPLYNVMSNSTYORRLERDCGF EbAV2 KDCCRMKNFNNEATAGPFLRLFGVKGKYGLKKLLEDEMWRYYDDFAQGRIDERGLPYFAARLGFRTKLMSEKKAWEKMQKGDPYGRAVMMLDALEQAASSPLYNVLTGVTFERRLEKECGF COAV1 PESVKMKNFNNDATAGPFLRAFGIKGKYGLKTLLEQVMWQFYDYYANNEVSDATLPFLTARVGFRTKLMTERKALEKMMVNDTYGRAVMMLDALEQAASSPLYNILSSQCFHGRLRRESGF GaAV1 FGCCSTKNFNNEATAGPFLRAFGVKVKHGLKTYLEQFMWGLYDRYGDGEINQKGLPHLTTRIGFRTKLVTREEALRKVQQGTTFGRAVMMLDALEQVASSPLYNVLSHKTFLMRNEPGSGF CdAV1 PGCCVMKNFNNEATSGPYLRGOGLKGKYGLKRILEAEMWRYYDSFASGECGLKNLPWFAARVGFRTKLLTOEVAWAKMOKGEALGRAVMMMDALEQAASSPMYNVLSSYTFRRRLEPRCGF MSAV1 PDACRVKNFNNFATSGPVLKAFGVRSKNGLRQLLQDEAWWYFNSFGNSDFGVEGLPWFGARLGFRSKLVTEEKARKKISEGDSVGRAVMMMDALEQCCSSPLYNVLSTYTFHKRLNRRSGF VCV-M PEACRVKNFNNFATAGPFLRRFGVKKKAGLRKLLEGEAWWYFNSFADGDLDVSGLPFFGARLGFRSKLVSEEKARKKISEGDSVGRAVMMMDALEQCCSSPLYNILSSYTYRRRLERECGF RHV-A LAECOCKTFNDQASAGPFLRAFGIKKKYGLRRMLEEFMWGIYDRYGDGRGDERSLPFITGRIGFRTKLLEEGEALRKIRNGEPLGRAVMMLDALEOISSSPLYNILSGYCGRNRNKGWCEF AOAV1 RACCNIKHFNVEATAGPFLRAFGVKKKESLEQLLGDFVWECFDDFATNDADIRRLPFFGMRIGFRTKLLKKSEMLTKIRDFKPLGRCVMMLDAIEQFCSSPLYNVLSKLSADALKDPMSGF FPAV1 RACCNVKHFNVEATAGPFLRAFGVKKKAALEQLLGDVWDCFDDFASNDGDARRLPFFGMRIGFRTKLLPRSEMLTKIKDFKPLGRCVMMLDAIEQFCSSPLYNILSNLSADALKDPLSGF CaAV1 KGSCRVKNYNDEATTGPFLYSFGIKKKYGLDNELQEIMENAYHHFAECKTSSSALPFFTARVGFRSKLLPMGEALRKFADNQPMGRCVMMMDALEQFASSPLYNVLSKYTSD-RSKGATSF STV KGSCHVRNYNDDATSGPFLWSFGIKKKYGLDKLLOSLMEDIYCHYSISEATDRALPYFAARVGFRSKLLTMGEAVKKFTECAPMGRCVMMLDALEOFASAPLYNVLSKYTAE - RSRGOTSF PPAV1 PEACRIKNYNDEATAGPWLRAFGVRRKAGLKSSLESLMWSFYDAVGDGKLLPEDLPYLSARVGFRTKLLAREAAMEKLGKGEPMGRAVVMLDALEQAASSPLYNVMSGLAAONHKKERGVF

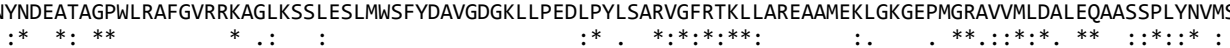

CiRV1 RNYLVRASASWIDFWDELKGAGTIVELDWKKFDRERPREDILFFIDIIISCFTAKTKREERLLAAYKRMMQRCLVDRVLMMDNGAYFTIDGMVPSGSLWTGICDTALNIMYITAALRSLGF FPAV2 RNYLVRASSAWADLWDELKSCGTIVELDWSKFDRDRPAEDIOFFVDVIISCFRPKNSRERRLLAGYRKMMENALVHRVMMLDDGSFFTLEGMVPSGSLWTGICDTALNIMYITSALRKLGF FPAV3 RNYLVRASVAWVEFWHELRDAKVIVELDWAKFDRERPAEDIQFFIEVICSCFQPRTAREERLLAGYKKMMENALVHRLIVLDNGCFLKVDGMVPSGSLWTGICDTSLNILYITAALMSLGH LPAV1 RNYLVRASVAWVEFWHELKDAKVIVELDWAKFDRERPAEDIOFFVDVICSCFOPKTAREENLLAGYKOMMENALVHRL IVLDNGCILKIDGMVPSGSLWTGICDTALNILYISAALISLGH BLV RNYLIRASSDWGKMYKEMRKAKVVVELDWKKFDRERPADHISFFIDVILSCFAPRTTREEKLLGAYRRAMENALLHRVLVTDDGGVLTVDGMVPSGSLWTGIIGTGLNILYIGYALSDIGI ZmAV1 RNMVVRASSDWSRFWGDIRNSCAIVELDWSKFDRERPKEDIEFVINIFVSCFLPKNRRERRLLSAYKYMMRKALIDKVIMLDDGCAFTYDGMIPSGSLWTGLLGTALNILYINAAVRRLGI ZmAV2 RNAVVRASSDWSRFWKDIRDAKCIVELDWSKFDRERPRADIQFCIDVLCSCFRPRGKRQRRLLSAYKYMLENALIHKVIMLDDGCAFEYEGMIPSGSLWTGILGTAMNILYITAACESCGV ACAV1 RNTIVRASSDWAKFWEEVKAAKVIVELDWKKFDRERPTEDLEFIIQVIISCFKPTDERERLFLRGYGIMLRRCLIDRYFITDDGGVFKIDGMVPSGSLWTGWVDTALNILYLQSVMISLGL ACAV2 RNTIVRASSDWAKMWEEVKKAQVIVELDWKKFDRERPTEDLAFMIDVIISCFKPENDRERLFLLAYKTMMQRCLIERFFVTDCGGVFKVEGMVPSGSLWTGWVDTALNILYLNAALLSLGF PeAV1 CNSIVRASSDWAMLWKDVSAASCVVELDWKKFDRERPADDISFMIDVIISCFEAKDDYEERLLLGYRIMLNRALIERCFVTDDGGVFHIDGMVPSGSLWTGWLDTALNILYIGAALRHVLP SCAV1 KNTIIRASSDWQAIWAHVKEAEAIVELDWGKFDRERPSQDLNFIVDVVVSCFAPKNSRERRLLRAYKLMMRAALVDRLLVLDDGTVFGIEGMVPSGSLWTGWVDTALNILYLKAACLEINI SPAV1 KNAVIRASSDWNEIWKGVREAEAIIELDWSKFDRERPAEDLEFIVDVVISCFKPRNERERRLLRAYGIMMRRALIERLLVMDGGGVFGIEGMVPSGSLWTGWIDTALNVLYLRSACLEVGL EbAV1 KNGIVKASSDWAKIWEDVREAKAIIELDWSKFDRERPADDILFVIEVVLSCFEPTNDRERRLLRAFGLMMRRALVERIIVMDDGGVFEIDGMVPSGSLWTGWLDTALNVLYLNAACMNVGI EbAV2 KNQVIRASSDWNRVWEYLRDSKVIIELDWAKFDRERPSEDLQFVIDVVLSCFAPRTPRERKLLEAYGIVMRRALIERAVVMDRGGVFTIEGMVPSGSLWTGWLDTALNILYLNAACVEAGY COAV1 RNALIRASSDWHFMWEEVOEAAVIVELDWSKFDRERPAEDIEFIINVVLSCFTPKTPREERLLRAYGIMMRRALIERLMITDNAGVFGISGMVPSGSLWTGWLDTALNILYIRAACREIGV GaAV1 RNATIRASSDWGKMWEEVROAATIVELDWSKFDRERPREDLLFIIEVILSCFLPKNRREKRLLEAYGIMLRRALVERVIVMDEGGVFTIDGMVPSGSLWTGWIDTALNILYILAACREIGV CDAV1 KNGVVRASSDWGVLWRRVQPAVIVELDWSKFDRERPREDLEFIVKVVCSCFRPRDRGRRLLOAYOEMMRRALVERALITDSGGVFLVGMVPSGSLWTGWIDTALNILYIKAICVELGI MSAV1 KNAVVKASSDWAHIWNGVKDAAVIVELDWSKFDRERPREDLEFMVSLISSCFNPKSAREERLLHAYTTSNFRALVERPVFLDGGGVFGIEGMVPSGSLWTGWLDTALNILYMKAVCAEIGV VCV-M KNAVVKASSDWAHVWGGVKEAAVVVELDWSKFDRERPREDLEFMVNVISSCFAPEGIRQRRLLEAYTVSNQRALVERPVMLDGGGAFCISGMVPSGSLWTGWLDTALNILYIKAVCAEIGI RHV-A RNTTVRASSDWGLLYSEVERAKCIVELDWSKFDRERPSRDILFVIKVIISCFEPRNGRERRLLEAYEIMLERALVHRLLLTDAGGVLEMEGMVPSGSLWTGWLDTAMNILYIRAACLGAGI AOAV1 RNTAVRASSDWSYMWEEIKEAKVCMELDWSKFDRERPRCDLEFMVDVVISCFAPKNEREQRLLRGYEVCMRRAIVERVALLDDGALFEIDGMVPSGSLWTGWLDTALNILYLSAALSEAGF FPAV1 RNTAVRASSDWSYMWEEIKOAKVCMELDWSKFDRERPRDDLEFIVDLVISCFTPRTEREORLLRAYEICMKRAIVERVAILDDGALFTIDGMVPSGSLWTGWIDTALNILYLSAALNQAGF CaAV1 RNSVVRASSDWMYLWDEVKEASVCVELDWSKFDRERPSADLLFMIDVIISCFEPSNRYEVRMLEAYGICMRRALVERVLITDDGGVFEIEGMVPSGSLWTGWLDTALNILYLNAALRHLDI STV RNTVVRASSDWMHFWDEVKEAAVCVELDWSKFDRERPSEDLDFMIKVICSCFRPKDEVEAKLLRGYGVCMRRALVERRLITDDGGVIHIDGMVPSGSLWTGWLDTALNILYIKSVLRSIDI PPAV1 RNYVVRASSQWRQLWDEVSSCKVLIELDWKKFDRERPPEDLLFMIDLVCSCFEPKSLREERLLAGYKVCMVRALMDRSFVLDSGSVFLVRGMVPSGSLWTGWLDTGLNALYLTHVFQDLGI 
CiRV1 DDSQFSPKCAGDDNLTVFGKKQGRARMERLRVRLNEWFRAGIETEDFIVHYPPYYVFTEQACFPPGTHLALGTSELLDMAEWVRFDGPCPIDEAAGRSHRWRYNFNAKPKFLANYFLRDGR FPAV2 DDSTFSPKCAGDDNLTCFORROGLDVMERLRTTLNEMFRANIDKKDFIVHYPPYAVTTVQACFEPGTDLSKGTSRMMDKAEWVPFTGPCPIDQAAGRSHRWKYVFTNKPKFLANFFLPDGK FPAV3 DITSFVPKCAGDDNLTTFDRRIRKKDLEKLRLRLNSLFRAGIKEEDFIIHYPPYHVTTVOACFPPGTDLSHGTSKMLDOATWVPFEGPCDINOEEGRSHRWKYQFEGKPKFLANFFLIDGR LPAV1 DITSFVPKCAGDDNLTTFDRRIRKKDLEKLRLRLNSLFRAGIKEEDFIVHYPPYHVTTVQACFPPGTDLSHGTSKMLDQATWMPFEGPCDINQEEGRSHRWKYQFEGKPKFLANFFLIDGR BLV SPLNYVPKCAGDDNLTFFSRDYGDAAFKRLRVKLNEMFRANIDEEDFIIHRPPFFVTKAQAVFPPGTDLSKGTSSILNQCKWVQFEGEIIIDEAMGLSHRWEYRFQGKPKFLANYWLPDG ZmAV1 PSDEFVPYCAGDDNLTVFKYPQRATRLGKIRGMLNEMFRAGIDPEDFIIHYPPFHVTKVQAKFPAGFDFTHGTSKFLDQCQWIPLKGNIHVDHSEGLSHRWNYVFKGKPKFLANYFMEDGR ZmAV2 KRETFVPFCAGDDNLTVFDSAVDEGMLLNIRVFLNNMFRAGIEEKDFLIHYPPYHVTKVQAVFPDDFDLSLGTSKYLDKCVWVPFEGPLLVDTSRGYSHRWNYVFKGKPKFLANYFLEDGR ACAV1 VSTAVSPKCAGDDNLTLFWKDFDDKRLLSIKTRLNAWFRAGIDDEDFFIHRPPYHVTREQATFPPGTDLTKGTSRKLKDAIWIPIDGEPIIDQAQGLSHRWQYVFRGKPKFLSAYWLEDGR ACAV2 NMTEVFPKCAGDDNLTLFMRDVENRRLLALKDRLNSWFRAGIEAEDFLIHRPPFFVTREOAVFPRGTDLTKGTSKIIGNAVWVPIEGEMVIDOEAGRSHRWOYVFRGRPKFLSAYWLEDGR PEAV1 DTSQAVAKCAGDDNLTLFYTDLPDASLLNLKKYLNEWFRAGIEDEDFIIHRPPYHITRFQATFPPGTDLSKGTSHLLDSAKWIQIHGIMNIDEAAGLSHRWKYSFAGKPKFLSCYWEENGN SCAV1 PSSQYLPMCAGDDNLTLFWKDPGP-ILARLRSILNDLFRANIDAGEFKIHYPPFHVVKKQACFPPGTDLSKGTSKIMHKAFWEEFVGELHVNEDLGKSHRWEYAFEHRPKFLSFYWLPEGQ SPAV1 PSQRYLPMCAGDDNLTLFWSDPGEVKLLKIRELLNEWYRAGIDDADFFIHRPPYHVVKRQACFPPGTDLKGGTSMLMKDAEWVEFEGELRVDEAAGRSHRWQYLFKGRPKFLSCYWTRDG EbAV1 GPLGFSAMCAGDDNLTLFWTDHPDHVLKRIKDELNGKFRAGISDEDFFIHRPPFHVTKOQACFPPGTDLSHGTSKLMDLVFWOVFDGEVVIDEAAGRSHRWEYVFKGRPKFLSCYWLPGGQ EbAV2 GPGFFHPMCAGDDNLTLFDLDLGDRRLLKIREVLNNWFRAGISEEDFFIHRPPFHVIKKOACFPPGTDLKIGTSKRMHEAFWVEFDGELVIDEAAGRSHRWEYIFKGRPKFLSNYWLPEGQ COAV1 SDONSFPKCAGDDNLTLFMRDPGDRALNRMKDILNKWFRAGI -KEDFFIHRPPYHVSKFOACFPPGTDLSEGTSKLIDEAEWIEFHDELEVDVSRGKSHRWEYRFKGKPKFLSCYWLENGR GaAV1 PSTFCSAKCAGDDNLTLFALDPGDGALRRLRVVLNEWFRAGIDEEEFLVHRPPYHVKKVQACFPEGVDISKGTSKLLDKARWEEFEGELRVDVAAGRSHRWEYRFKGCPKFLSCYWLRDGK CdAV1 ALSAVEVFCAGDDNLTLFMYDPGDVILKEFRTLLNQYFRAGIKEEDFFIHRPPFDVRKYQATFPVGSDLRGGTSRMLDRATWIEFEGEIEVDEARGRSHRWEYRFKGKPKFLSNYWLPDGR MSAV1 GDDDVEVMCAGDDNLTLFKFDPGEANLRRIRDLLNDWFLAGISEDEFLIHRPPYHVTKVQACFPEGTDLSRGTSGMLKKAVWVPFEGEVVIDNARGRSHRWEYRFSGCPKFLSCYWLHDG VCV-M GAEDIEVLCAGDDNLTLFKYDPGDSRLOTMKNLLNDWFRAGISDEDFIVHRPPFHVTKVOACFAPGTDLSHGTSKILKDAAWIPFEGELVRNDHTGRSHRWEYRFSGCPKFLSSFWLSDGL RHV-A ASDLYSSRCAGDDNLTLFWEDQSDGILGLVKQHLNNWFRAGIKDEDFIICRGPYYVERYQATFPIGTDLSEGTSRLMDSAIWVRLEGGPIIDANRGLSHRWEYRFHGKPKFLSCYWLPDGR AOAV1 SSYMARPKCAGDDNLTLFMEDVPDGRLIOVRGLLNDWFLAGIKDEDFAITRAPFHVETYQAVFPPGTDLTKGTSKIIDOCEWVRFEGOLQINQEOGLSHRWOYRFKGKPKFLSCYWLADGR FPAV1 SLDTARPKCAGDDNLTLFLEDVTDSRLFYVRDLLNEWFLAGIKEKDFNITRPPFYVETYOAVFPPGTDLSLGTSKIVDQCEWVRFEGOLYINOEEGHSHRWOYRFKGKPKFLSCYWLQDGR CaAV1 APSSASPKCAGDDNLTLFYRDPGDEVLLRLKVVLNEWFRAGIKDEDFVITRPPYHVRTYQAVFPSGLDLSKGTSKIIHKAYWREFEDEVRVDMERGLSHRWEYRFKGCPKFLSCYWLEDGR STV LEEEAVPKCAGDDNLTVFSKDPGDEVLEEMRVKLNDYFRAGIKKEDFIITRPPFHVRTFQAVFKEGTDLSKGTSKIMKKAYWREFEDELRIDQEKGLSHRWEYRFKGAPKFLSCYWLEDG

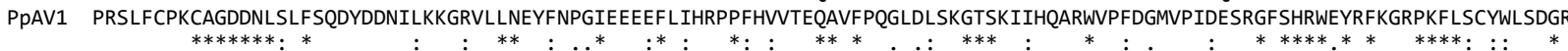

CIRV1 PIRPAQDNLEKLLWPEGIHKTIEHYEAAVISMAVDNPFNHHNINHLMHRYVIIQQIKELSY-DVDPDIVMQMAAIRAKPGQPVPYPMVAFYRRQEDKVVLEEVPELSHVIKRFQKFVASVS

FPAV2 PIRPAHDNLEKLLWPEGIHESIEDYMAAVLSMVVDNPFNHHNVNHMMHRYLIAOOIOKOSI-FIDPAVVMELAKTRPKHGEAVPFPEIAYYRKCEGYVDIEREPEFOEFFKSFREFISSVS FPAV3 PIRPAHDNLEKLLWPEGIHGTLEDYQAAVLAMVVDNPFHHNVNHMMHRHLIAAQISRQAF-DVDPAIVMELCTSRAEPGELVPYPEIAFYRRVEGYVDLDAVPEFKEILDDFRLFVSSVS LPAV1 PIRPAHDNLEKLLWPEGIHGTLEDYQAAVLAMVVDNPFNHHNVNHMMHRHLISKQISRQAF-DVDPAIVMELCTSKGEPGELIPYPEIAFYRRVDGYVDLDAVPEFKEILDNFRLFVSSVS BLV SIRPATDSLERLLYPEGLHQTIEDYEMAVLAMVVDNPWNSHNVNHMMHRFCIVQQIKRQSMVGIKAEDVMWYSKLRGKEGEGIPYPQVAYWRRQEKKVFMEEIPELMGYIKKFQTFLSGVS ZmAV1 SIRPAHDNLEKLLYPENVQQKIEDYEAAVLSMAVDNPWNSHNINHLMQRFCIIQQIKROAVHPLTAGDVLFCAKFOSISENMWMFPTVGAWRRQLLNVRMEDIEELKPTVEAFSEFVRGVT ZmAV2 SIRPAHDNMEKLLFPENIOEHIEDYEAAILSMVVDNPWNSHNVNHLMORYVIVOOIKROSIPPLNAAEVLFCSKFREIADNMYLFPTVGYWRROLPGVRMESIPELRPIVEEFSOFVSGV ACAV1 PIRPTHVNAEKLLFPEGIHKDIEQYESAVLSMIVDNPYNHHNVNHCMHRFIICEQVKRQSAAGIDPVDILWFSRIRPGNPDVVPYPMVASWRRCEGYVDLEQLPFISDYVKDLKEFVAGV ACAV2 PIRPTHINSEKLLFPEGIHDSIDTYEAAVLSMVVDNPFNHHNINHCMHRFVICEQVKRQARMGLDPIDILWLSRFRSSVGEEVPYPMIASWRRQDTWVDMEQLPFVRDYVRDFREFVSGV PeAV1 PIRPAHVNLEKLLWPEGIHKTIDDYLAAVISMVVDNPFNHHNVNHMMHRFCIIQQVKRLSVAGIRDDHILSLAHIRGKEGEMVPFPMVAEWRRTQGWVDMESMPYLKKYISDFRHFAAGV SCAV1 PIRPTRDNLEKLLWPEGIHKSLDDYEAAVASMVVDNPWNHHNVNHLLMRYVIIOOIRSLAATDVKVLDLLWFSKFRPVGDEEVPCPMVAPWRRRSPHARMEDYPEVORWVRDFKDFVAGV SPAV1 PIRPTSDNLEKLLWPEGIHKSIDDYEASVASMAVDNPFNHHNVNHMLMRYVIIOOIRRVSAGILSPEECLAFCKFRSOEGEEIPYPMVAPWRRGMHEARMEDYPETKPWVKEFRDFISGVS EbAV1 PIRPTSDNMEKLLWPEGIHEDIDDYOATVMAMVVDNPWNHHCVNHLLMRYVILOOLRRVDILRGGMDDVLFLCACREKGGGPIPYPMVAPWRRSEVHGRMEDYEEVKRHIODFSDFVTGV EbAV2 PIRPTRDNLEKLLWPEGIHKDLNEYQAALMAMVVDNPWNHHAVNHLLMRYVIVQQLRRVNSGLGREDDTLFLAGLRDMTGGVIPFPMVAPWRRGAQQGRMEDYKEVQNWCLDFQSFVTGVT COAV1 PIRPAADNLEKLLWPEGVHDKLEIYEAAVASMIVDNPWNHHNVNHLLMRYIIIQQIKRLGVGPANVEDVLFLSQFR-NEGEEIPFPQVAPWRKFKEHVVMEEYNEVMEHVENFKNFLSGV GaAV1 PIRPAADNLQKLLWPEGIHDSLDVYEAAIASMVVDNPWNHHNVNHLMSRYVIIQQVRRFSAGIVPHEMCVWLSKFRGNAGEPVPYPMIAPWRRMDTHQQLEAYPEAVVEMEVFRDFVQGV CdAV1 PVRPTRDNLEKLLWPEGVHATLEDYEGAVISMVVDNPFNHHNVNHMLMRYVIIOOLRRMSVAVGELDLLLKLGKIRAKGDEEVPMPOIAPWRRGELOAKMEDYNDAORHLAVFEDFMRGVS MSAV1 PIRPAHDNLEKLLWPEGLHDDIDVYEGAVISMVVDNPHNHHNCNHMLSRFIIIREARRLGASVEDPFIPIKHGSIRPVGDEPVPYPELAPWRRAPGGYKLEDYPENAEHIQVFRDFMQGVS VCV-M PIRPASDNLEKLLWPEGTHSDLNVYEGAVISMVVDNPHNAHNVNHLLSRYIIIQEARRLGAAVEDPMIPLRLARHRPVGDEVVPYPDLAPWRRHPEPFQLEDYPANADHIAIFKDFVQGVA RHV-A PIRPAHDCLEKLLWPEGIHGDLETYEAAVISMIVDNPFNHHNVNHMLVRYVLIQQIKROVVSPMTAEDIVYLCKFRDREGGSVPYPMIGPWRRGQKOGRMEDYPEVGRDIKNLKGFVAGIS AOAV1 PIRPASDNVEKLLYPEGIHKSVEDYISACLAMVVDNPFNQHNVNHMKHRYLIAQQIKRILVTGIPDRLVLALARIRPDGEEDIPYPMIAPWRRFKEYIDLDSYEPVQQWIKEFDDFVAGIS FPAV1 PIRPASDNVEKLLFPEGIHKDIDDYIAAVLAMVVDNPFNQHNVNHMKHRYLIAQQIKRVMVSTIPYQLILALSRIRSEAGEDIPFPMIAPWRRFKEWIDLDKYPPVQEWIRDFDDFVAGIS CaAV1 PIRPSSENLEKLLFPEGVHSSIDDYIASVLSMVVDNPFNDHNINHLKHRYLIAMOIKRLSAAGGRCGDIMDLARIRPRHDEEVPVPOIAVWRRVKEYIDLDEYGPTKHYIDEFNSFVTGVT STV PIRPSHENLEKLLYPEGVHANIDDYIAAVLSMVVDNPFNHHNINHLKHRYIIANQVKRLSAAGGRCEDILRLARIREREDEEVPVPQIAVWRRVKEYVDLDSYEPAKYYIQDFNAFVSGV

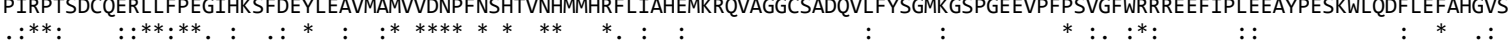

CiRV1 TLYTRKAEGGIDSWKFMDIIRGEHSIGTGQFGNDVLVWCKFLSENRLTRSLRAARRFRVQAEGKVAEDDVLWKVGLIFDEVFNFCKSESVIS-PIHYADFVSKRLKEYNSK - - - - - - FPAV2 TLYARRSEGGIDAWRFMDIIRGQHSIGAGQFGNSVHEWCRFLGEHPLTRSLRKARRFRPMKEAVVADPETLGKVEKAFTWVLDLCEANDPMT -PLFYASAVSDILSSNVSAP--- - - FPAV3 TLYARRTEGGIDSWRFMEMIRGEHSIGEGQFGNDIYEWCKFLGSNPLTRSLRATRRFKMKAPATVADEGTIRKVQEAFTWLTSICEENLIVT-PMYLAQLISDKLLL - - - - - - - - LPAV1 TLYARRTEGGIDSWRFMEMIRGEHSIGEGOFGNDIYEWCKFLGSNPLTRSLRATRRFKMKTSATVVDEPTRKKVOEAFOWLTSICEENLIVT-PMYLAOLISDKLLL - - - - . - - - - - -

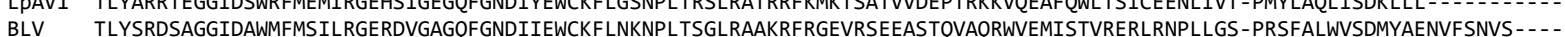
ZmAV1 SLYSRASTGGLDSWQFMEILRGERDAGSGQYGSDIEAWCAFLNRNGLTRSLRPAKRYRKEKQTYQSAEAG-DKILVSLAAIYATSDYDLREDRDLGFIIRISNELRKQLL - - - - - - ZmAV2 SLYGRASSGGIDAWQFLDILRGDRDLGSGQYGNDIEKWCAFLNRNALSRSLRPARRFRQGTAPVEPDAKGRESLSR - LALLYEVPSSDRKDSRRLNFISRISVMLKQFVS - - - - - - ACAV1 SLYARDSIGGLDAWRFTEIIRGETDLGTGQFGNDIDVWIHWLHHHPLTKYLKPIKRHRQPPLSVMPDKELHGRIEEALQVYRDIRGTTTNAS-AEAFSLFLSNVIKHQG - - - - - - . -

ACAV2 SLYSRQSTGGLDSWKFTSIIRGETEFGEGQFGNDIDDWISWMYRNPMTKYLRPIRRFRAVGEEVRPDRELSGSLQRCIGIYRQIRGTQENSS-SENFAIFLSNVLRQTRSYRDANAHP

PeAV1 SLYAROPGGGIDAWRFMDMIRGNVLLGGEOFGNDFRDWIKFLONNPLTSYLKPMRRFRPOKAARESTEDIISKF-KSFSACCGIGDGRTPFASTESYGSWIADLVPRMOHGKAPLATM

SCAV1 SLYARSPTGGVDAYHYMDILRGYARVGEGOFGNELIHWCDWLGRHPVTKYFKAARGFROAPVAVVLPEEELLPIRLHFEVLREKLTSGVWES -VDDFCNWLVTKHHVS - . - . - . - - -

SPAV1 SLYARKPTGGVDAYRFMEIIRGEQSPGEGQFGSDLVKWVDWLRKHPVTKFLRATGGRHHQKSTARLEGEDLRKVEDAFMALRERLGSGQVGS-TEDFSLWVSDLLRSGM- - - - - - - - -

EbAV1 SLYSRTATGGVDSWLFMNIIRGEQHVGEGQYGNDLMVWVSWIRDHPCTRYLKSVRGLRTRVEQLDVDPGLLQKATIHYSLLRETLVSGRIET-ALDFARWVRSIILGGHV- - - - - - - - .

EbAV2 SLYTREATGGMDAWQFMEIIRGDHHVGEGQFGNDLMRWLQWMASHPCSKYLRPVRGLRPGKSAVTAEREDLDRAVNGFNTLRRLLSSGRLCS-SLDYALWISHSVIDSLPG- - - - - - -

COAV1 SLYARRAEGGVDAWKFMEIIRGESHVGEGQFGNDLIDWLKWMHVHPMTKFLRGTRMFRTPSEEIVAGDEEMDAAVEAFNVLIERVESEEFQD-VESFAKWVSNMLRENVLPHQ-----

GaAV1 ALYVRQAEGGIDAWKFMDILRGEGTVGEGQFGNDLRGWLRWMYAHPMTRHIRKVRGFTEPGTPAIADPATMQRTTYAFRILHEKLKAEEFNA-SEDFAIWLSTVIRQQKSR - - - - - - -

CDAV1 TLYSRAPEGGLDAWOITDIMRGMGSVGEGQFGNETLSWLKWMHHHPLTRYLRAARRYODPSMPVELEPSORAEALRAFEALRGRLLYDGFAS - SEEYAIWVARLVKLRYLA- - - - - - -

MSAV1 SLYLREATGGVDAWQFMDIIRGDAFVGEGQFGNDLRSWLNWLHHHPISKYLRETKTFRLKDGADPDAPKDLEKAGRALRALRGRLELGGFAC-VEDFVRWLDGIRSSRE - - - - - - - -

VCV-M SLYLRVPTGGIDAWQFMDVIRGDAFVGEGQFGNDLRTWLAWLHNHPISKYLRETKTFRLTEGIDPDQPVEVDKAARAFRALRGKAETGGFHS-VDEFVEWIHSATKET - - - - - - . - . - .

RHV-A TLYARKGGGGIDAWRFMDIIRGDADLGQGQFGNEVLEWARWLGRHEVTKFLRPIKRMRAEHGEVIIEGEGRRQAEAALRALREILNEGTHRS-CLDFSFFLSDRLRASCEDPRR - - - -

AOAV1 GLYVRSTTGGIDAYKFMDFIRGDAVIGEGQWGNEMDRWIRFITEHPVSRSLRKARRHNPASVPSAQVNQYYQRAAEGLNVYRQQLVNHRLDS-SREYGLWVSDLLRR - - . - . - . - -

FPAV1 GLYVRSTTGGIDAYKFMDFIRGDSVIGEGQWGNEMTRWIRFVTEHPVSRALRKARRFNPKAAPTAGENLFYTRAQGGLNAYRRQLQNHRLES-SEEYGLWVSDLLRQK - - - - - - - - - -

CaAV1 SLYARATTGGLDAYKVMDLIKGNSPIGRGOWGNDVMAWIRFVRDHPATRYLKETRRYKDEMIHIDOOTPLRPEVTGALAILSNALFNYVYED-SREFSLSIANRIRTKRSVN - - - - - STV SLYARSSTGGLDAYKVMDLIRGNATIGRGQWGNDVMDWIRFVRDHPATKYLKGAKRFREQHNQEPTTAKPSKDARRAIKLLRNSLINEAYAD-SNSFAISISERLRRKKPTR - - - - - PpAV1 TLYVRDSAGNLDAWMFMEILRGERAVHPDQIGSDVDAWLTFLRENALTKYLRPIRRLRPEVKAKEYSEQDTSQGRAALLRLRDGVLNREWKN-GADFAMYISNLLICNVQQDLQ- - - - 